\title{
Reconstructing cold climate paleoenvironments from micromorphological analysis of relict slope deposits (Serra da Estrela, Central Portugal)
}

\author{
Alexandre Nieuwendam ${ }^{1} \odot$ | Gonçalo Vieira ${ }^{1} \odot$ | Carlos Schaefer $^{2} \odot$ | \\ Barbara Woronko ${ }^{3}$ () | Margareta Johansson ${ }^{4}$ [
}

${ }^{1}$ Centre of Geographical Studies - IGOT, Universidade de Lisboa, Portugal

${ }^{2}$ Departamento de Solos, Universidade Federal de Viçosa, Minas Gerais, Brazil

${ }^{3}$ Faculty of Geology, University of Warsaw, Poland

${ }^{4}$ Department of Physical Geography and Ecosystem Science, Lund University, Sweden

\section{Correspondence}

Alexandre Nieuwendam, Centre of Geographical Studies IGOT - Rua Branca Edmée Marques, 1600-276 Lisboa, Portugal.

Email: alexandretn@gmail.com

Funding information

Fundação para a Ciência e a Tecnologia, Grant/ Award Number: SFRH/BD/68511/2010;

Centro de Estudos Geográficos, IGOT -

ULisboa, Grant/Award Number: FCT UID/GEO/00295/2013; Portuguese

Foundation for Science and Technology, Grant/Award Number:

$\mathrm{SFRH} / \mathrm{BD} / 68511 / 2010$

\begin{abstract}
The paper focuses on analysis of macro- and micromorphological characteristics of relict slope deposits in Serra da Estrela (Portugal) to understand the significance of different slope processes and paleoenvironmental settings. Micromorphology is a useful sedimentology technique allowing significant advances compared to macroscopic techniques. Results show that different processes are involved in the development of the slope deposits, reflecting different environmental conditions. The main processes responsible for the emplacement of the relict slope deposits are solifluction, debris-flow and runoff, but postdepositional changes are also present. Solifluction was identified in slope deposits between 650 and $1500 \mathrm{~m}$ a.s.l. The common microfeatures identified are circular arrangement of grains with a core grain, rounded vesicles, vertical grains, matrix deformations and fine-grained deposits. Slope deposits above $1300 \mathrm{~m}$ a.s.l have a platy microstructure and coincide with the altitudinal range of the relict rock glaciers, indicating the elevation limit of permafrost. Below this altitude platy microstructures are less frequent. Slope deposits in northfacing slopes were affected by frost-induced processes in a seasonal frost regime, followed by a postdeposition illuvial phase. Debris-flow and runoff were identified in slope deposits between 680 and $1260 \mathrm{~m}$ a.s.l. The common microfeatures are oblique grains, grain dumps, and coarse and fine grain lineations, and banded microstructures were identified in runoff processes. Debris-flow deposits have a circular arrangement of grains without a core grain, identified in sediments in paraglacial and periglacial environments. The slope deposits show evidence of past periods of enhanced periglacial activity since the last glaciation until the Younger Dryas.
\end{abstract}

\section{KEYWORDS}

micromorphology, paleoenvironments, periglacial processes, sedimentology, slope deposits, slope processes
[Correction added on 22 June 2020. In the acknowledgement section "Associação Geopark Estrela (AGE)" has been added in this version].

\section{1 | INTRODUCTION}

Slope deposits are sediment accumulations in a slope position or near its base, which essentially result from the action of gravity and reflect 
the influences of weathering (physical and chemical), transport (slopewash and mass movements), rock type, and previous and current climate. ${ }^{1,2}$ Slope processes are characterized by their own stress field and stress heterogeneity and the resulting slope deposits are expected to be diverse macroscopically and microscopically. ${ }^{3}$ Slope deposits are found in all climatic regions and produce a limited number of similar landforms (e.g., talus deposits, cones, fans, depositional glacis or more widespread slope mantling sedimentary covers) that can result from more than one process. ${ }^{4}$ Studies have shown that different processes act together on the surface of the landform, so determining the mechanisms involved in each process requires careful analysis. Some processes are active only under limited specific environmental conditions (e.g., periglacial environments) and are associated with specific processes. $^{3,4}$ As a result, they can be used in paleogeographic and paleoclimate reconstructions to better understand the landscape responses to climatic fluctuations during the Quaternary. ${ }^{4}$

The macroscopic characteristics of different types of slope deposits are well documented, ${ }^{4-8}$ whereas investigations on the associated micromorphological features are scarce. ${ }^{9,10}$ Consequently, there is a general recognition of the need for micromorphological classification of slope deposits. ${ }^{3}$ Micromorphology provides an insight into the identification, description, and interpretation of components, features, and fabrics in soils and sediments. ${ }^{11,12}$ It offers insights into various problems relating to processes involved in sedimentary environments and the processes of formation (deposition, deformation, and/or emplacement). ${ }^{3}$ Micromorphological studies of frost-affected soils and sediments have shown that many different microfeatures are cryogenic. ${ }^{13}$ Van VlietLanoë et al. ${ }^{14}$ and Harris ${ }^{15}$ combined information from active, fossil, and experimental data to analyze microstructures caused by repeated freezing and thawing. The microstructures most frequently described in periglacial settings were platy structures and grain coatings. Combined, these microstructures were used to reconstruct the presence of segregation ice in the active layer and the process of gelifluction. ${ }^{3}$ Platy structure has been identified in other periglacial studies and related to cryoturbation, ${ }^{15}$ differential frost heave, ${ }^{16}$ and permafrost. ${ }^{17}$ Other microstructures developed under periglacial conditions have been identified using micromorphology; for example, Elliott and Worsley ${ }^{18}$ observed well-developed orientation of grains in solifluction sediments, Mol et al. ${ }^{19}$ described grain cracks in sediments due to a sudden drop in temperature, and van Vliet-Lanoë ${ }^{20}$ identified granular structures in sediments affected by periglacial conditions.

The Iberian Peninsula mountains, including Serra da Estrela (Portugal), are of interest because a wide variety of periglacial deposits and landforms are present, not only at high altitude, but also as relict deposits in mid- to low-altitude environments, which show evidence of past periods of enhanced periglacial activity. ${ }^{21}$ The periglacial boundary shifted altitudinally, generally in response to the intensity of the cold periods during the Quaternary glaciations. ${ }^{22}$ Early studies of geomorphological processes related to cold climates in the Iberian Peninsula focused on geomorphological mapping, description, and relative dating of relict landforms and slope deposits. ${ }^{23-33}$ Recently, monitoring of present-day processes has increased in the Iberian Peninsula mountains, ${ }^{34-36}$ but only a few studies provide absolute dating of periglacial features. ${ }^{21}$ The complexity of factors such as rough orography, high Holocene erosion rates and land degradation, has made it difficult to provide a chronological framework for the sedimentation, and additional geographic locations need to be investigated to allow reconstruction of the regional characteristics of Iberian periglacial paleoenvironments. ${ }^{21}$

Relict periglacial landforms and deposits in Portugal are found mainly in the northern and central mountains, ${ }^{37}$ with evidence from glacial landforms and sediments suggesting the occurrence of several cold phases during the late Pleistocene. ${ }^{23,33,38}$ Although several studies exist on relict slope deposits in the Portuguese mountains, ${ }^{23-25,30,33,39-41}$ most lack a detailed sedimentological analysis, as well as an absolute chronological framework, limiting their application for paleoenvironmental reconstruction. Texier and Meireles, ${ }^{42}$ using macroand micromorphological analyses in mid-altitude mountains in northern Portugal, did not observe frost-related structures that originated in Pleistocene cold-climate phases, contradicting previous studies. ${ }^{23,33,38}$ Vieira ${ }^{33}$ highlighted the need to study slope deposits in more detail in Serra da Estrela (the highest mountain in Portugal), clarifying their genesis, exploring the possibilities of chronologically framing them, and evaluating their paleogeographic significance.

The main aim of this paper is to contribute to a better understanding of the morphogenetic significance of different types of slope deposits in Serra da Estrela. We also clarify the role of cold environment processes and their contributions to the Late Quaternary evolution of the slope environment. This study is the first using a detailed micromorphological investigation on the relict slope deposits in Serra da Estrela and one of the few in the Iberian Peninsula.

\section{2 | STUDY AREA}

Serra da Estrela is a granite mountain located in central Portugal and is part of the Iberian Central Cordillera (Figure 1). The mountain massif is roughly rectangular and elongated in a SW-NE direction, being ca. $45 \mathrm{~km}$ long and up to $20 \mathrm{~km}$ wide. ${ }^{41}$ It is limited by two steep fault scarps that constitute the boundaries of the massif with a relative relief of over 1,000 m. The upper area of Serra da Estrela includes two plateaus, divided by the NNE-SSW tectonic lineament of the Zêzere and Alforfa valleys. The western plateau is the highest with an altitude of 1,400-1,993 $\mathrm{m}$ a.s.I., while the eastern plateau lies below $1,750 \mathrm{~m}$. The altitude of the plateau at the boundary between granite and metamorphic rocks in the north is $1,200-1,400 \mathrm{~m}$ a.s.I.

Vieira et al. ${ }^{33}$ studied in detail the glacial and periglacial geomorphology of Serra da Estrela. This included sedimentological analysis of glacial and fluvioglacial deposits, modeling of the glacier surfaces, and the description of several sites showing stratified slope, head, debris flow deposits and a detailed geomorphological map. They concluded that most of the western plateau area was glaciated during the Last Glacial Maximum (LGM), when a plateau icefield with several radiating valley glaciers was present, leading to a morphology dominated by glacial landforms. On the eastern plateau, only small glaciers occurred, and periglacial features have developed. In this paper we study the granite areas of the western and eastern plateaus, the Zêzere and 


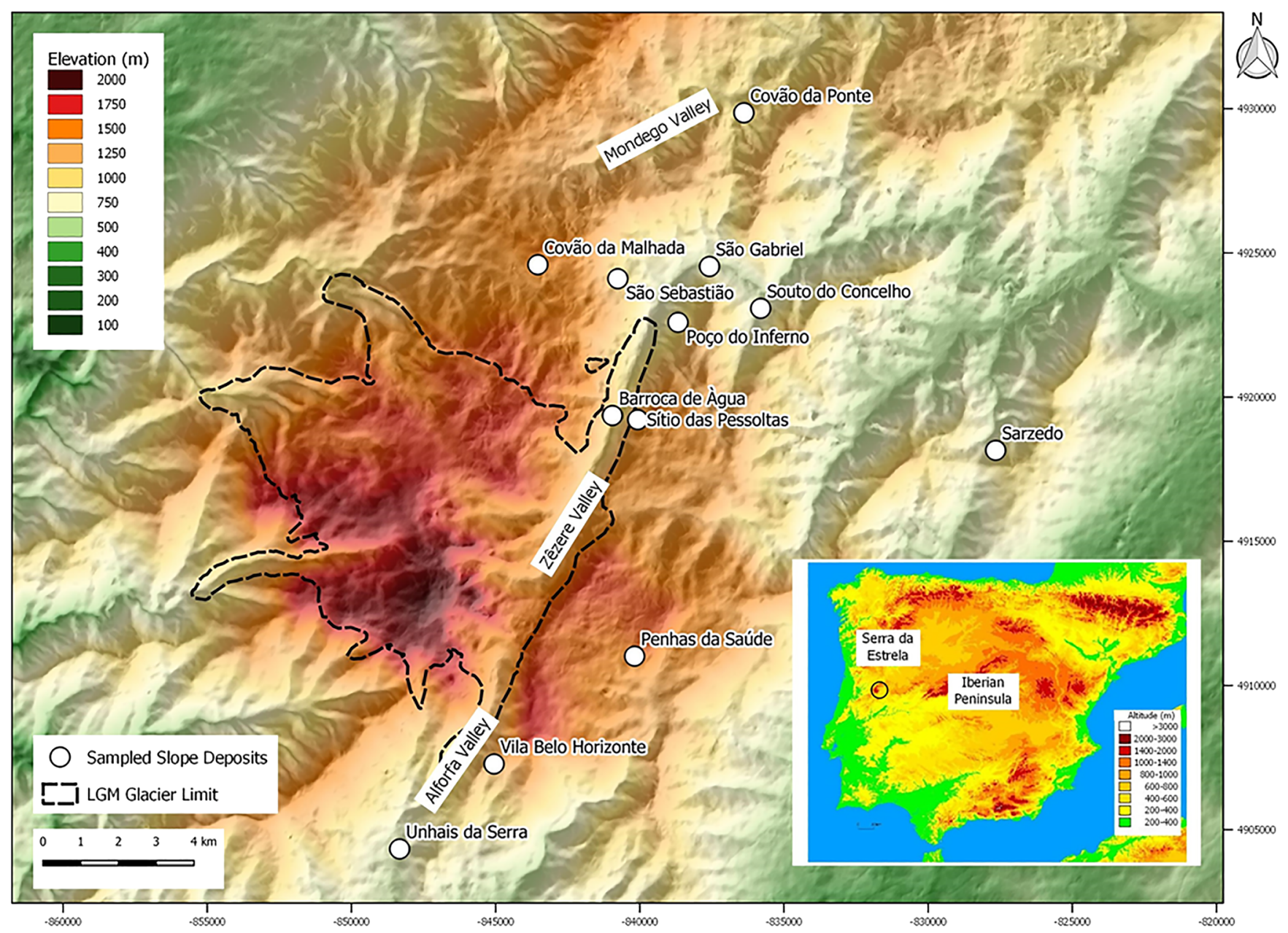

FIGURE 1 Location map of the study area. Penhas da Saúde (PS, 1,520 m); Covão da Malhada (CM, 1,500 m); Sítio das Pessoltas (SP, 1,300 m); Vila Belo Horizonte (VBH, 1,260 m); São Sebastião (SS, 1,010 m); Poço do inferno (PI, 1,008 m); Barroca de Água (BA, 1,000 m); Covão da Ponte (CP, 990 m); Sarzedo (SZ, 830 m); Souto do Concelho (SC, 700 m); São Gabriel (SG, 680 m); Unhais da Serra (US, 650 m) (elevation data: NASA Shuttle Radar Topography Mission)

Alforfa valleys, and the metasedimentary area of the Mondego Valley to the north of the plateaus (Figure 1). Seventeen slope outcrops located between 650 and 1520 m a.s.I were studied. General characteristics are described in Table 1, Figures 2 and 3, and details are found in the Supporting Information (Appendix S1).

Vieira ${ }^{37}$ proposed a relative chronology based on geomorphological analysis of the relationships between glacier and periglacial evidence and on thermoluminescence dating indicating that the Last Maximum of the Glaciation of Serra da Estrela (LMGSE - ca. 30 ka BP) occurred before the LGM. Palynological analysis and radiocarbon ages from organic infills of glacial basins suggest that small glaciers still existed into the Late Glacial and periglacial activity occurred in the Younger Dryas. ${ }^{43,44}$

\section{3 | MATERIAL AND METHODS}

The samples were collected from different slope deposits, located between 650 and 1,520 $\mathrm{m}$ a.s.I within and outside the maximum glacier extent (Figures 1, 2 and Table 1). After removing overlying debris, the face of the slope deposits was excavated to provide a fresh surface for field analysis and sampling. The profiles were described macroscopically directly in the field, using criteria based on Hubbard and Glasser, ${ }^{45}$ with a focus on general organization of deposits, characteristics of the layers, macrostructure, presence and type of bedding, grain-size, and clast morphology.

One sample (Souto do Concelho) was dated using ${ }^{14} \mathrm{C}$ accelerator mass spectrometry (AMS) and calibrated using the CALIB 7.1 software together with the IntCal13 curve. ${ }^{45}$ Dating was performed at the 14Chrono Centre of Queen's University Belfast.

For micromorphological analyses, 30 undisturbed and oriented samples were collected from the different facies and depths from each slope deposit using a steel Kubiena box $\left(10 \mathrm{~cm}^{3}\right)$. The undisturbed samples were not impregnated with resin in the field, for the purpose of transport, because the material was insufficiently indurated. Thin sections were produced and interpreted at TERRANTAR research lab, Federal University of Viçosa, Brazil. Each thin section sample was dried at $50^{\circ} \mathrm{C}$ and impregnated with a $1: 1$ crystic resin/styrene mix 


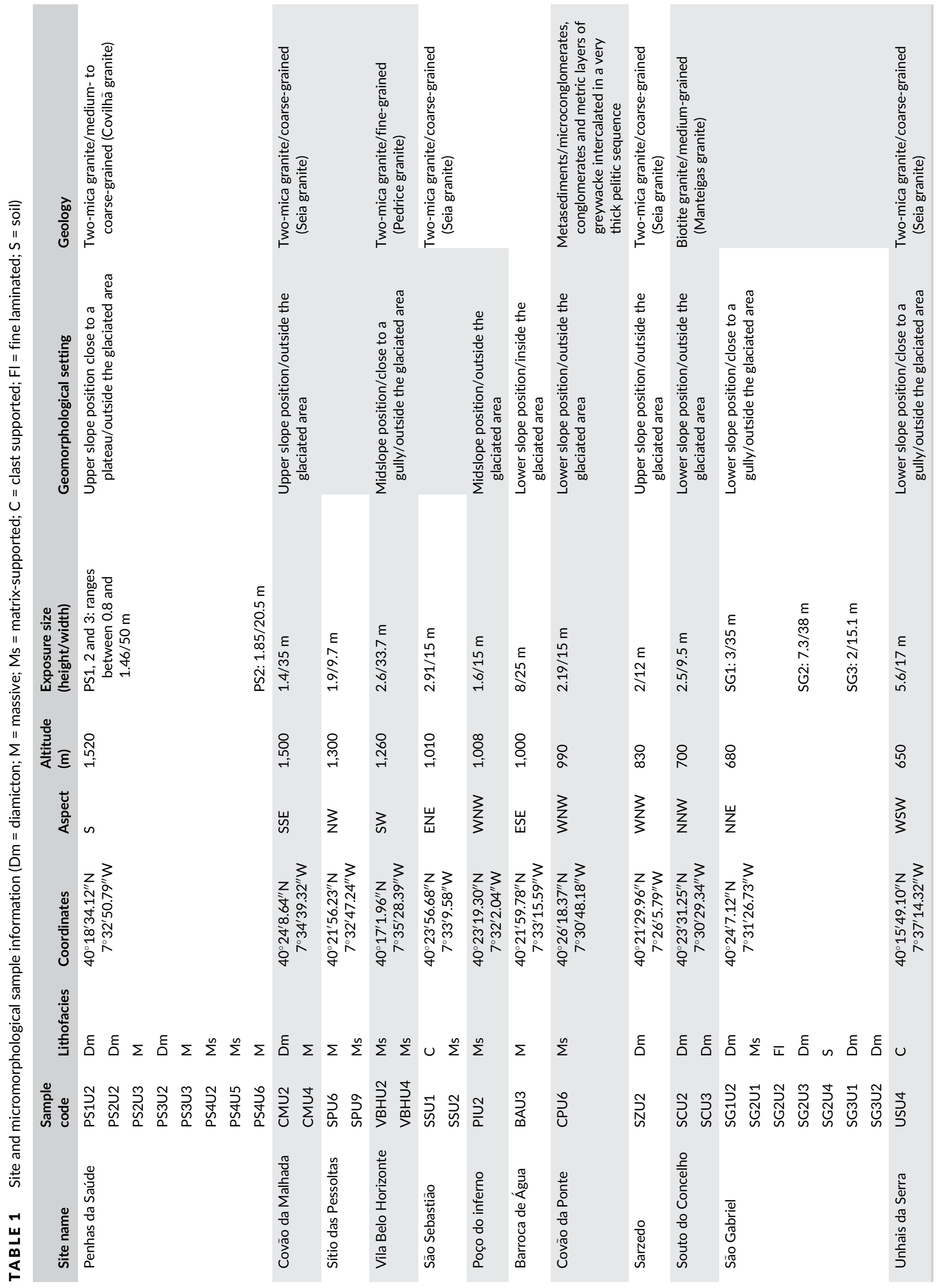



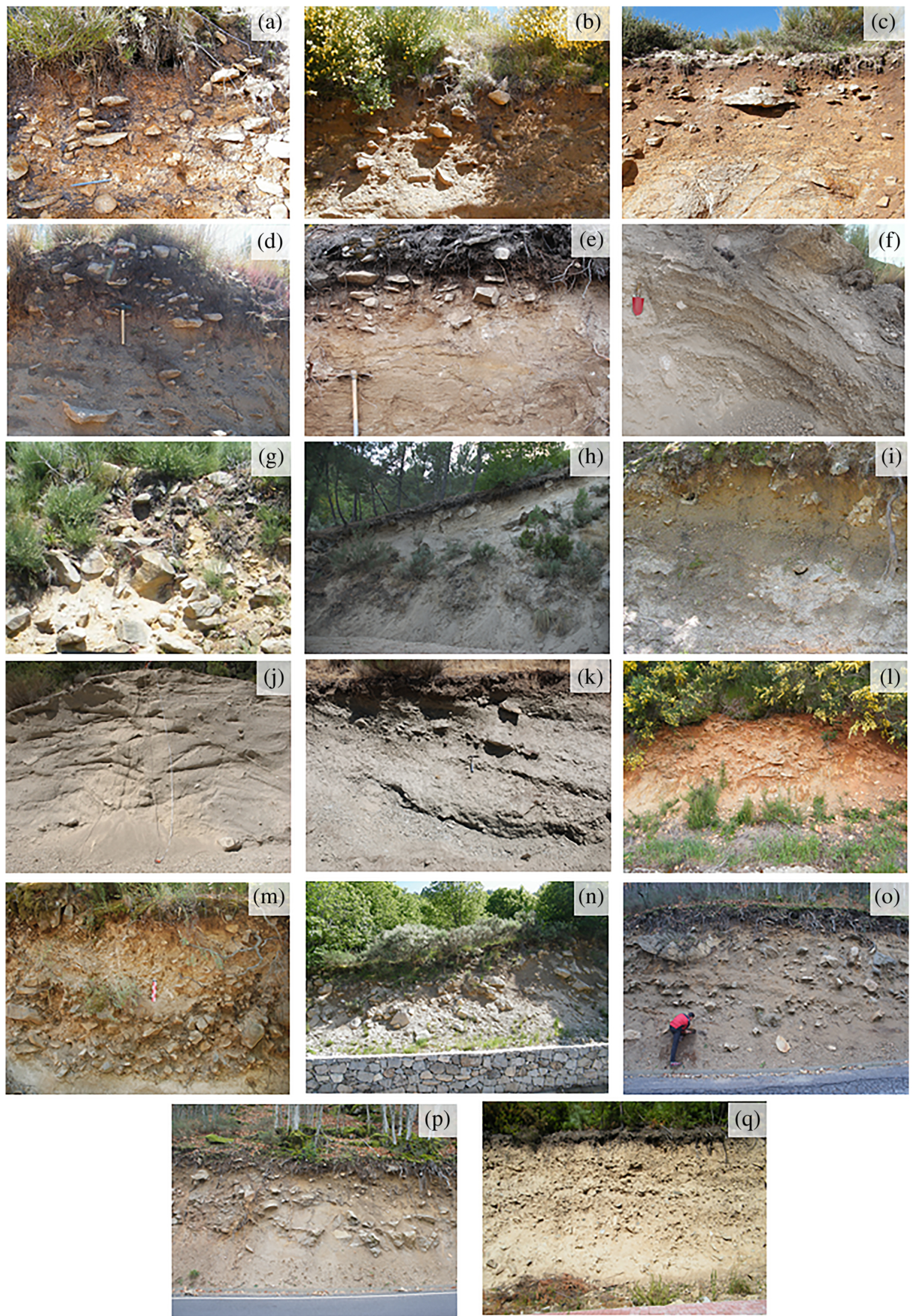

FIGURE 2 Overview of the 17 studied slope deposits. (a) Penhas da Saúde (PS1); (b) Penhas da Saúde (PS2); (c) Penhas da Saúde (PS3); (d) Penhas da Saúde (PS4); (e) Covão da Malhada (CM); (f) Sítio das Pessoltas (SP); (g) Vila Belo Horizonte (VBH); (h) São Sebastião (SS); (i) Poço do Inferno (PI); (j) Barroca de Água (BA); (k) Covão da Ponte (CP); (I) Sarzedo (SZ); (m) Souto do Concelho (SC); (n) São Gabriel (SG1); (o) São Gabriel (SG2); (p) São Gabriel (SG3); (q) Unhais da Serra (US) 
(a)

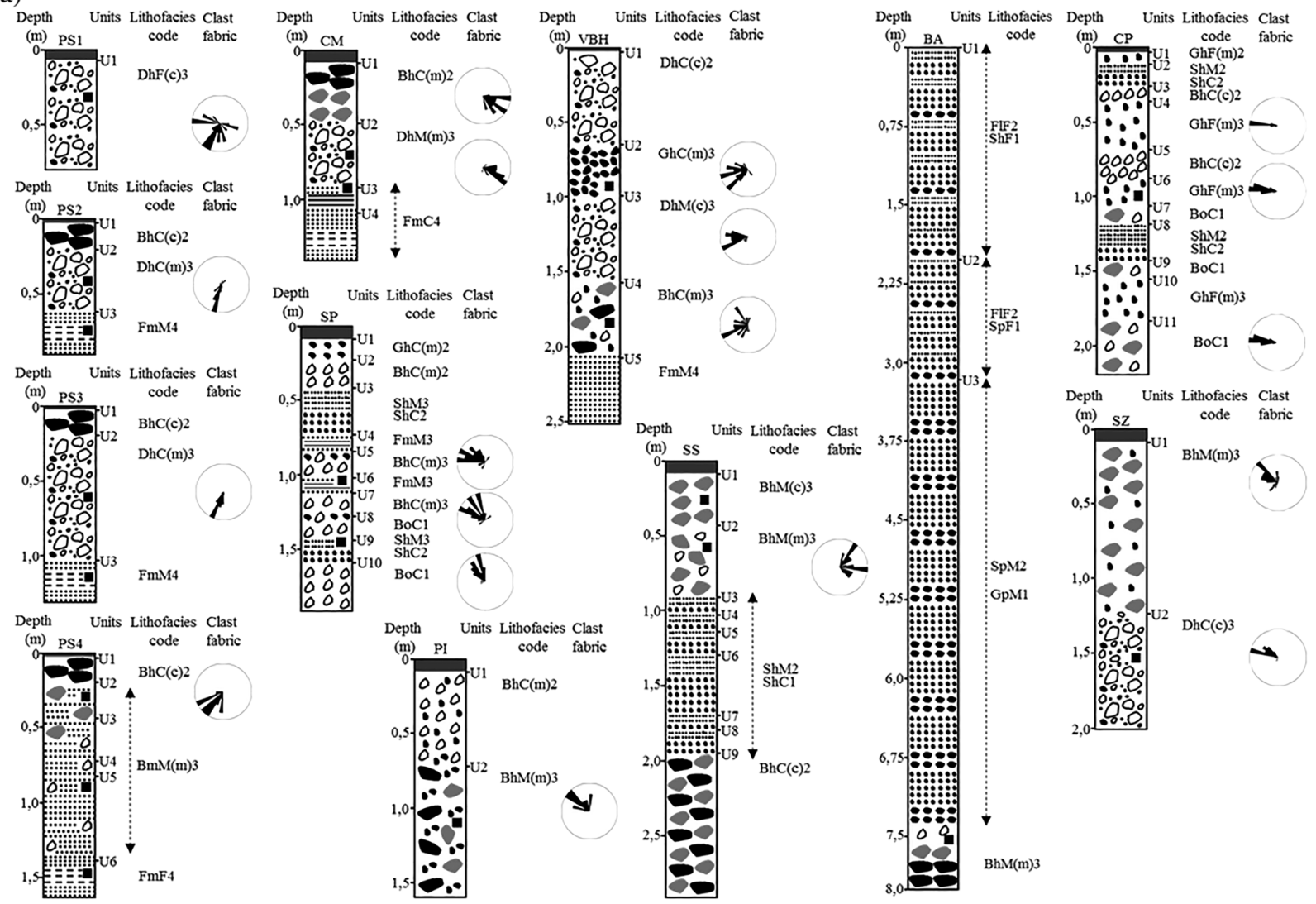

(b)

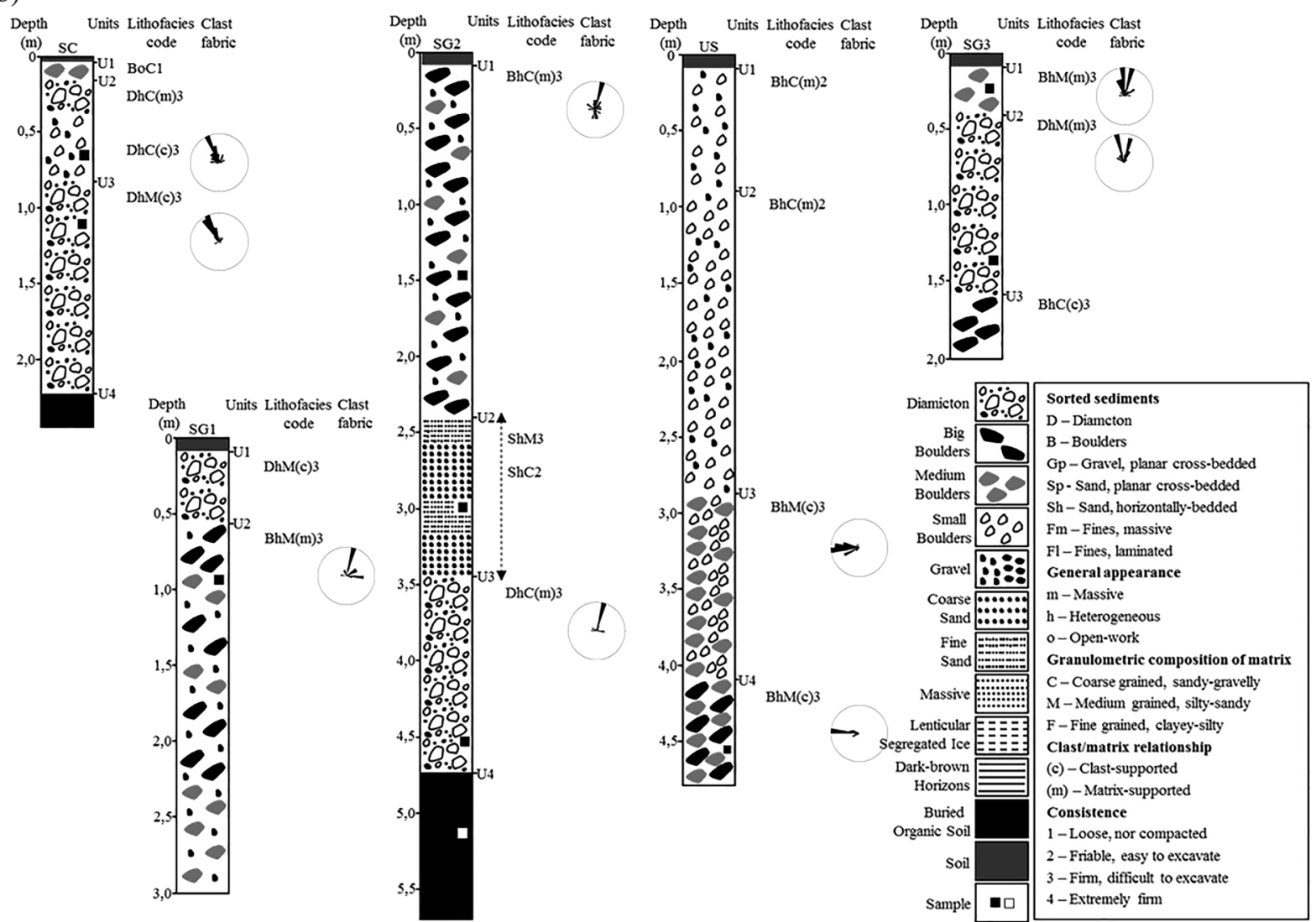

FIGURE 3 Sedimentological logs from the 17 studied slope deposits in Serra da Estrela (for locations see Figure 1) 
poured onto samples at atmospheric pressure. Impregnated samples were cut into blocks of $0.5 \mathrm{~cm}$ thickness using a diamond saw, and polished with corundum abrasives from 250 down to 600 mesh. After ultrasonic cleaning, the polished blocks were mounted onto glass slides followed by polishing and hand-finishing to produce $30-\mu \mathrm{m}$ thick, $10 \times 6-\mathrm{cm}$ sized thin-sections. No cover slips were used to allow for further scanning electron microscope/energy dispersive spectroscopy analyses, and fine ultrapolishing using diamond powder of decreasing size (60 to $1 \mu \mathrm{m}$ ) ensured that a flat surface was produced. Thin-sections were first examined under Zeiss polarizing microscope (OTM level) using an attached Pentax camera fitted with a Zeiss exposure meter in the Federal University of Viçosa (Brazil), and later with a Nikon Eclipse LV100POL polarizing microscope with an automatic table in the University of Warsaw (Poland). Micromorphological descriptions and terminology stems from original soil science studies and since then supplemented by terms common to structural geology ${ }^{3}$ following classifications developed by Brewer, ${ }^{46}$ Bullock et al. ${ }^{10}$ and Stoops. ${ }^{47}$ Particular attention was given to the type of voids, microstructures, coarse vs fine (c/f) related distribution, and specific microfeatures ${ }^{47}$ (Figure 3). Description of the specific microfeatures followed Todisco and Bhiry, ${ }^{48}$ Stoops et al. ${ }^{49}$ and Linch and Dowdeswell. ${ }^{50}$

\section{4 | RESULTS}

The text below provides macro- and micromorphological descriptions of units from all 30 samples. Detailed macroscopic descriptions of the complete slope outcrops can be found in the Supporting Information (Appendix S1). Sedimentary facies for all samples are shown in Figure 3, and the results of semiquantitative analysis with visual estimates ${ }^{48,50}$ of microscopic components are presented in Tables $2 \mathrm{a}$ and $2 \mathrm{~b}$.

\section{1 | Macroscopic description}

Samples were collected from units with distinctive sedimentary characteristics (Table 1, Figures 2 and 3): diamicton, bouldery units, stratified beds, and fine-grained sediments.

\subsection{1 | Diamicton}

The diamictons are matrix-supported (not often clast-supported) and are coarse or medium-grained (Figure 3). Subangular (most common) to subrounded boulders show a moderately to well-developed preferred orientation parallel to the slope inclination. Boulders with weakly developed preferred orientation parallel to the slope inclination are only observed in the São Gabriel deposit (SG1U2 and SG2U3) (Figure 3b).

\subsection{2 | Bouldery units}

The units composed of boulders are macroscopically heterogeneous (most common) or massive and are clast- or matrix-supported and coarse- or medium-grained (Figure 3). However, the distribution and size of the boulders can be variable. Generally, they have a moderately or well-developed preferred orientation parallel to the slope inclination. Deformation features such as folds are observed in São Gabriel (SG3U2) and Unhais da Serra (USU4).

\section{\begin{tabular}{l|c} 
4.1.3 & Stratified beds
\end{tabular}}

Gravel/coarse sand beds and/or coarse/fine sand beds in a normal graded-bedding are common (Figure 3). Gravel and coarse sand beds are aligned mostly horizontally and range between 30 and $100 \mathrm{~cm}$ in thickness. Fine sand beds are horizontally bedded and range from 10 to $30 \mathrm{~cm}$. These units can extend vertically for several meters in the slope deposit (e.g., Sítio das Pessoltas, São Sebastião, Barroca de Água, and Covão da Ponte) (Figure 3).

\subsection{4 | Fine-grained sediments}

Fine-grained sediments were observed in the lower part of the visible section of the outcrops (Figure 3a). They are massive and lenticular segregated ice-form lenses (platy structure) and can be observed in the field in Penhas da Saúde (PS2U3, PS2U3 and PS4U6) and Covão da Malhada (CMU4) deposits. Massive units with dark-brown horizons are observed in Sítio das Pessoltas (SPU6 and SPU4) and Covão da Malhada (CMU3) (Figure 3a). Radiocarbon dating was performed for these dark-brown horizons, but the results were not relevant for the present research.

\section{2 | Micromorphological description}

A summary of micromorphological structures, using a semiquantitative analysis with visual estimates, is illustrated in Tables $2 \mathrm{a}$ and $2 \mathrm{~b}$. Their microfeatures are illustrated in the photomicrographs in Figure 4.

Most of the samples show more than one type of void (Table 2a). Vughs and planar voids are found throughout the samples in moderate and high abundance. Compound and complex packing voids are less frequent. The most commonly observed types of vughs are equidimensional, irregular, and star-shaped and are often found in association with perpendicular planar voids. Vughs are also frequently observed in samples with compound packing voids (Table 2a).

Samples with moderately and well-developed vughs and planar voids are associated with massive, platy, angular, subangular, and/or spongy microstructures (Table 2a). Compound packing voids are often connected with granular microstructure. Well-developed complex packing voids are associated with moderately developed compact and pellicular microstructures or with moderately developed intergrain microaggregate, bridged, and pellicular microstructures (Table 2a).

A chitonic $\mathrm{c} / \mathrm{f}$-related distribution is the most dominant distribution pattern throughout the samples, found at moderate and high abundance (Table 2b). A porphyric c/f-related distribution shows 


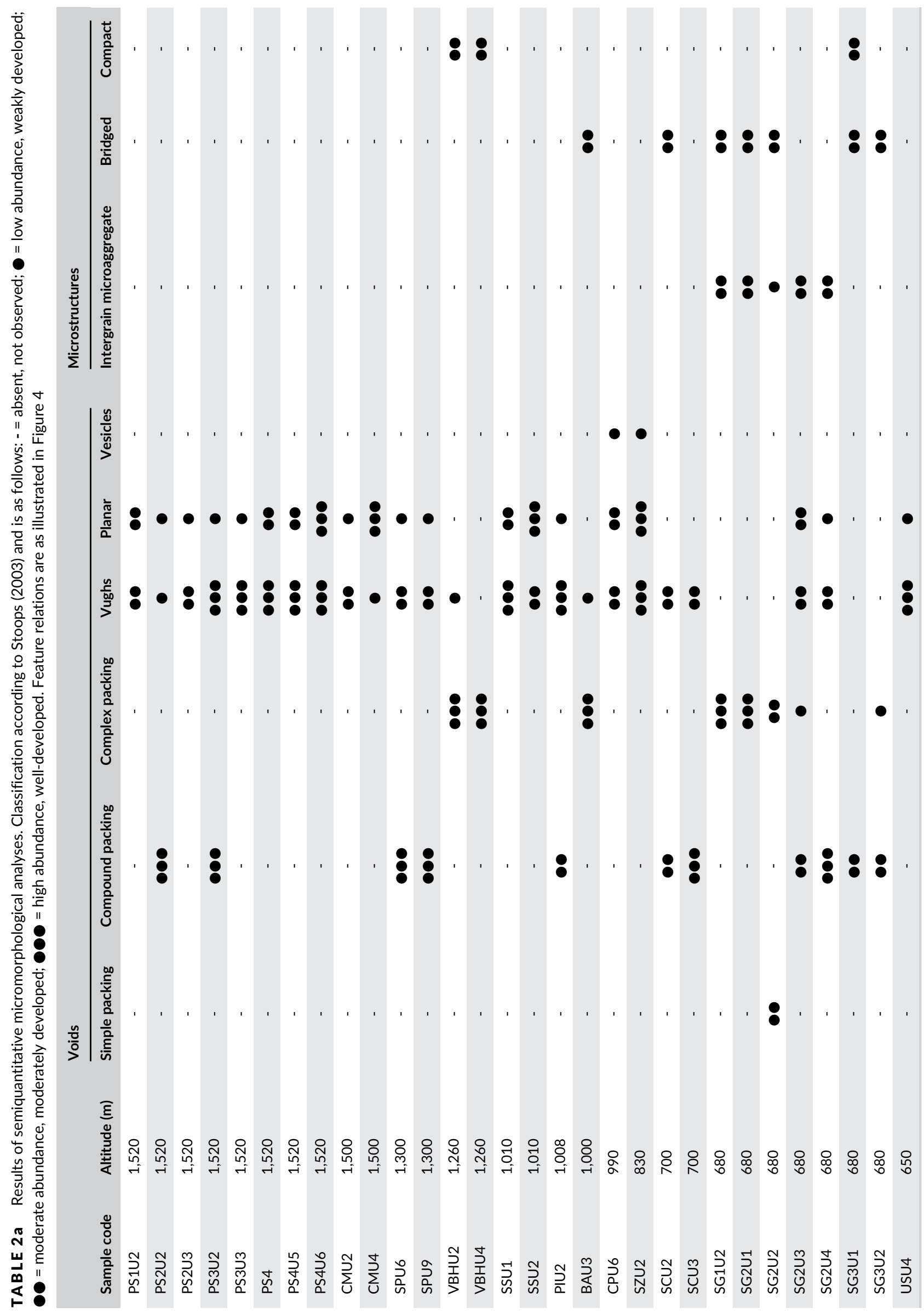




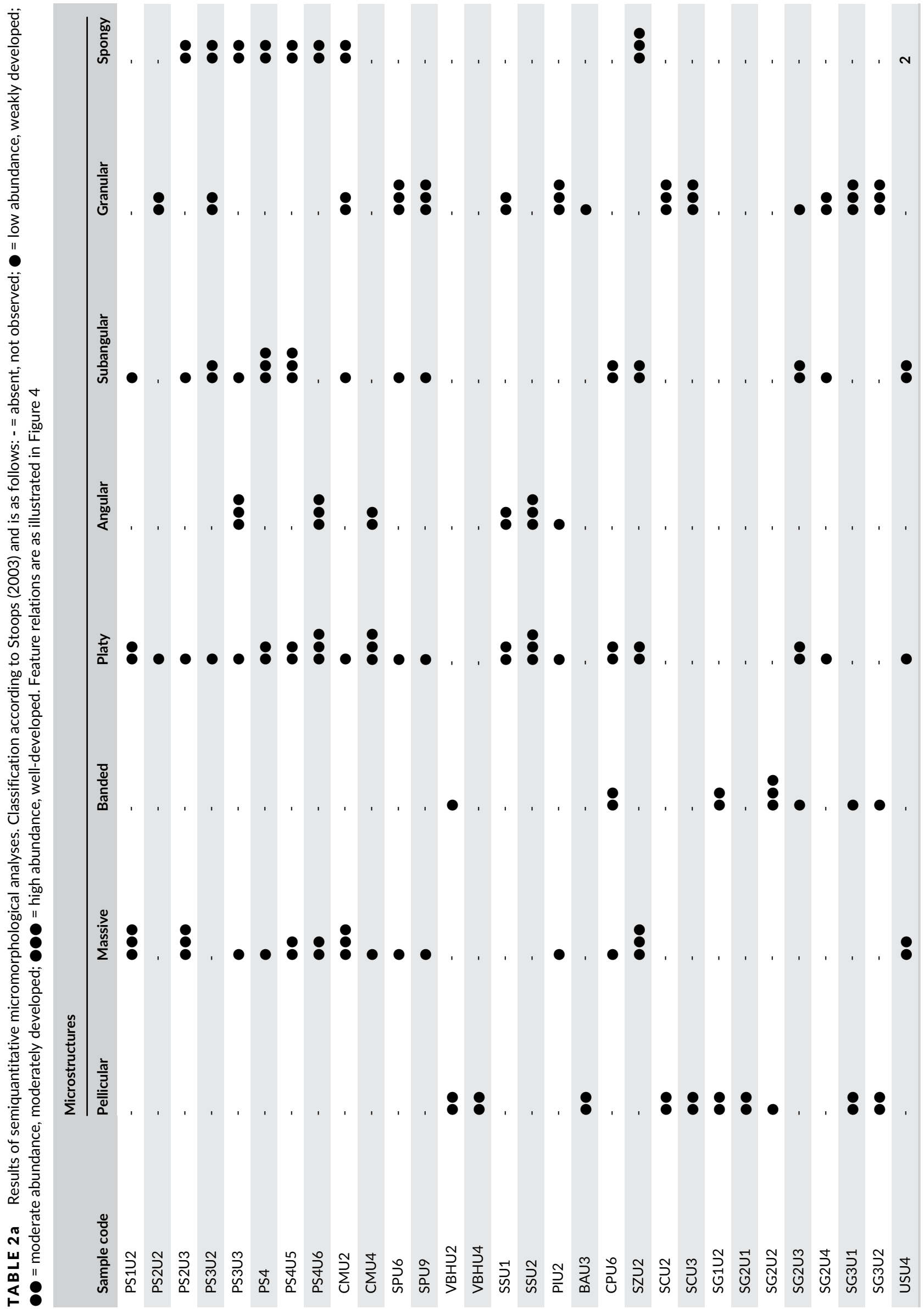




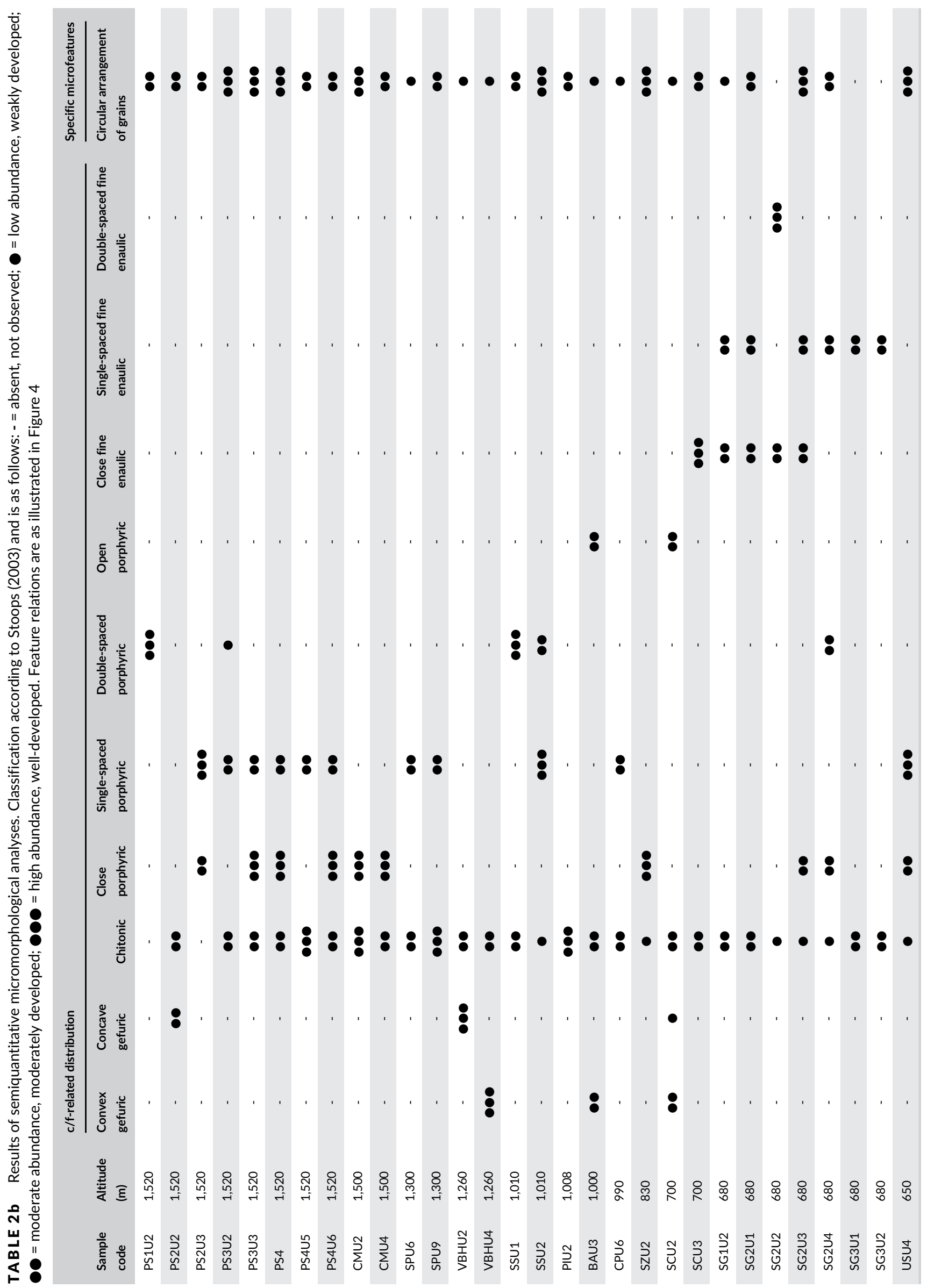




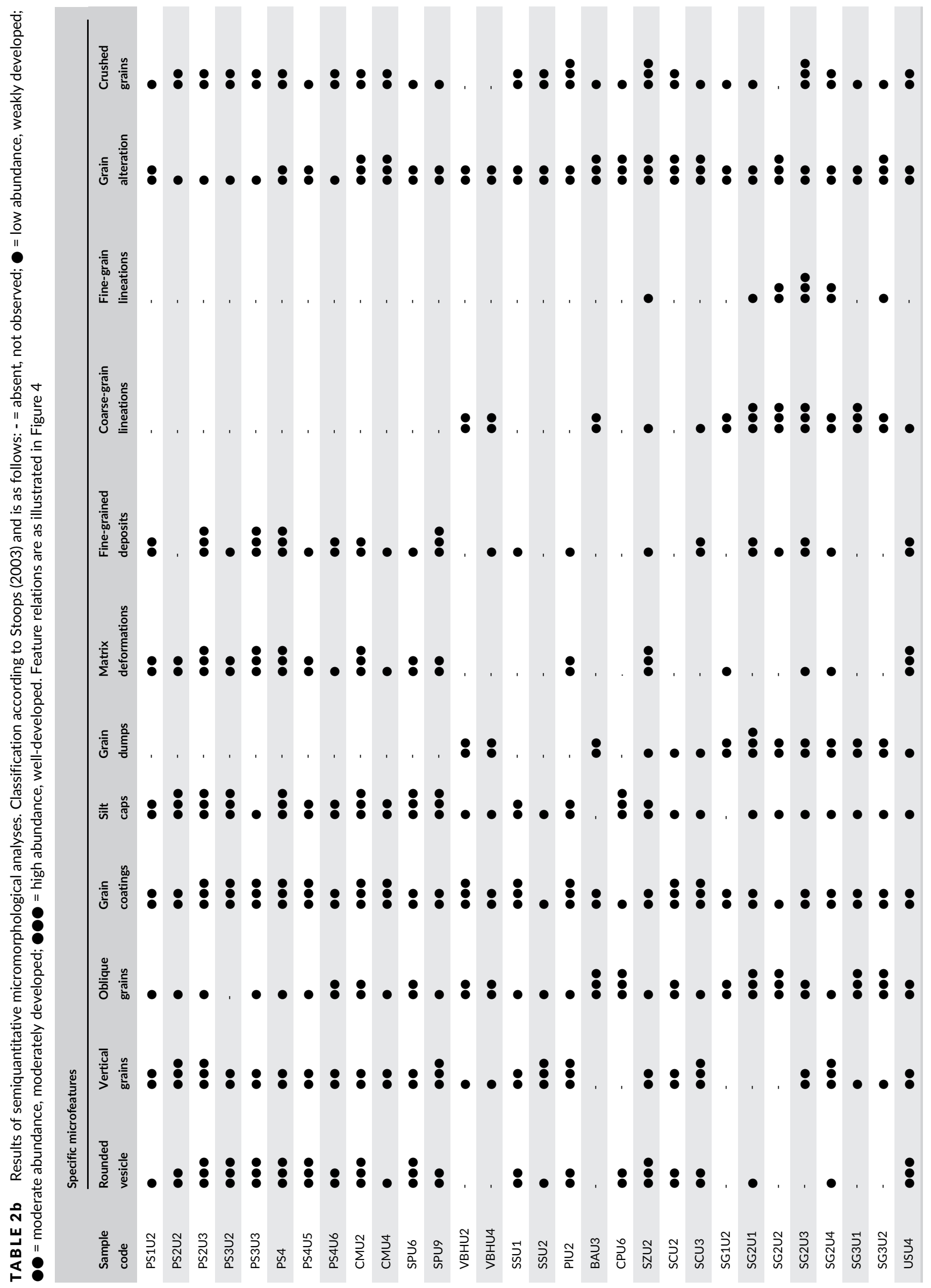



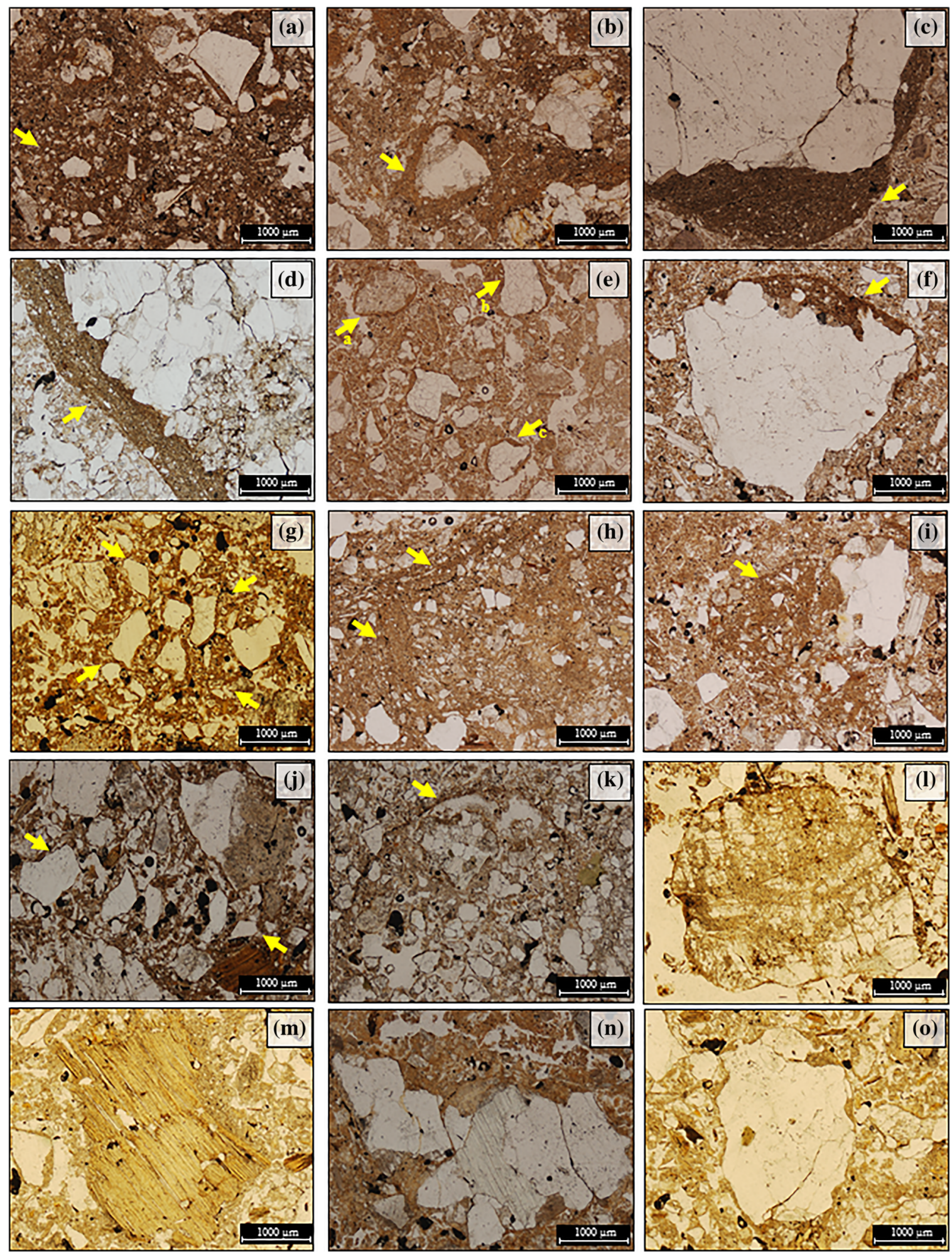

FIGURE 4 Specific microfeatures of the slope deposit samples. Individual features are annotated in yellow. (a) Circular arrangement of grains with a core grain (PS4U2); (b) rounded vesicle, matrix around a clast (PS4U5); (c) grain coatings, laminated type with alternating laminae thickness, texture and color (SPU9); (d) grain coatings, layered type with alternating layers with different textures (CMU2); (e) vertical grains (a), oblique grains (b), grain coatings (c), nonlaminated type where coating appears as a homogenous body (PS4U6); (f) silt caps, coating covers the top of the grain (PS3U2); (g) grain dumps, concentration of a group of eight grains (SG2U1); (h) matrix deformations, alternating coarse- and fine-grained lineation's (USU4); (i) fine-grained deposits, matrix-rich semi-circular domains (SPU9); (j) coarse grains lineations, five grains without contact in a line (SG2U4); (k) fine grain lineations, thin oriented line (SG2U3); (I) grain alterations, cross-linear pattern (SG2U2); (m) grain alterations, parallel pattern (SG2U2); (n) crushed grains, smooth fracture (SZU2); and (o) crushed grains, spheroidal fracture (PIU2) 
several subtypes in more than one sample and are based on the distance between the coarser units. Moderately to well-developed close and single spaced porphyric are frequently observed in the samples collected in the Penhas da Saúde, Covão da Malhada and Sítio das Pessoltas (Table $2 b$ ). Three subtypes of enaulic distribution were distinguished based on the relative distance between the coarser grains. Close fine, single-spaced and double-spaced fine enaulic distributions are moderately abundant in the samples from São Gabriel (Table 2b). Gefuric indicates smaller units linked to larger units and bridges can be convex or concave. Convex gefuric types are moderately to welldeveloped and observed in VBHU4, BAU3, and SCU2 and concave gefuric is well-developed and observed in VBHU2 (Table 2b).

Most of the samples have more than one type of specific microfeature (Table 2b). Circular arrangements of grains comprise a concentric or circular pattern of grains with (Figure 4a) or without a core grain. They are a very common feature and are observed throughout the samples. Concentric arrangements of grains with a core grain are found in moderate to high abundance in samples from Penhas da Saúde, Covão da Malhada, Sítio das Pessoltas, São Sebastião, Poço do Inferno, Sarzedo, and Unhais da Serra. In the remaining sites we observed an arcuate or spiral arrangement of grains without a core grain

A rounded vesicle consists of a preferential sorting of matrix around a clast or void (Figure 4b). They are frequently observed in the same samples where circular arrangements of grains are developed around a core grain.

Vertical or near-vertical oriented grains and oblique or nearhorizontal grains are also frequently observed in the samples. Vertical grains are generally found in moderately and high abundance in the same samples where the circular arrangements of grains are developed around a core grain, whereas oblique or near-horizontal grains are observed in the remaining samples.

Grain coatings consist of fine material $(<63 \mu \mathrm{m}$ ) (silt or clay) covering completely or almost entirely a grain or void (Figures $4 c-e$ ) and silt caps (or capping, Figure 4f) only cover the top of a grain. Grain coatings are observed in all samples (Table $2 b$ ). The analyses of grain coatings and silt caps show that most of the samples have more than one type. The most frequent type of coating is laminated (Figure 4c), followed by layered (Figure 4d), nonlaminated (Figure 4e) and compound layered. While the laminated type was found in all samples, layered types were more specifically observed in Penhas da Saúde, Covão da Malhada, Sítio das Pessoltas, São Sebsatião, and Poço do Inferno; compound layered in samples from the first three sites; and nonlaminated in samples from Vila Belo Horizonte, Souto do Concelho, and São Gabriel.

Grain dumps are concentrations of grains in groups of more than three elements (Figure 4g) and are moderately abundant in Vila Belo Horizonte, Barroca de Água, and São Gabriel (Table 2a).

Matrix deformations are matrix-rich domains alternating between coarse- and fine-grained material arranged in bands or lineations (Figure 4h). Fine-grained deposits (Figure 4i) are matrix-rich semicircular domains observed in coarse material. Both these microfeatures are moderately to well-developed and are found in samples at Penhas da
Saúde, Covão da Malhada, Sítio das Pessoltas, and Unhais da Serra (Table 2a).

Coarse grain lineations (Figure 4j) comprise four or more grains without grain-to-grain contact in a line, and fine grain lineations (Figure 4k) include a very thin oriented line. Both microfeatures are found in moderately and high abundancy, simultaneously, in samples from São Gabriel. Coarse grain lineations are moderately abundant in samples from Vila Belo Horizonte.

Grain alteration (Figure $4 \mathrm{l}, \mathrm{m}$ ) is moderately to well-developed in all samples (Table 2a) and most samples show more than one type of pattern. ${ }^{47}$ Crushed or fractured grains are observed in almost all samples (Table 2b). Smooth fractures (Figure $4 n$ ) and spheroidal fractures (Figure 40) are the two most common types of splitting found on the quartz grains.

\section{5 | DISCUSSION}

From the results of our micromorphological analysis it is possible to interpret different types of processes in the context of different environmental settings. ${ }^{51}$ (Table 3 ). In each of the following sections, textures/structures are grouped according to the dominant processes responsible for their formation or deposition. It is possible, in some cases, to differentiate overlain microstructural patterns in the deposits, indicating overprinted deposition events. Generally, all the samples show a varied composition of different microstructures and microfeatures, indicating that the sediments have been subject to extensive mechanical reworking. ${ }^{12}$ This could be expected in this type of deposit as a result of the complex nature of slope processes.

\section{1 | Penhas da Saúde (1,520 m) and Covão da Malhada (1,500 m)}

The slope deposits from these two sites are generally characterized by a diamicton with well-developed preferred clast orientation parallel to the slope and by the presence of massive units with platy structures associated with ice segregation (Figure 3a). These macroscopic features are indicative of solifluction, ${ }^{7,8,20,52-55}$ a process generally related to periglacial environments. ${ }^{56}$

Microscopically, the samples display variably shaped vughs, features which have been associated with air or water ejection under pressure or to cryoturbation stresses. ${ }^{49}$ Cryoturbation is a dominant soil process in permafrost regions and refers to all soil movements due to frost action. ${ }^{57}$ Although some cryoturbation may occur in areas of seasonal frost, it most commonly occurs in permafrost areas. Starshaped vughs are also often observed, associated with blocky microstructures (angular and subangular). They are evidence of freezing in soils, especially in lower horizons (excluding PS3U3 and PS4U6, Table 2a). ${ }^{20}$

Planar voids (Table 2a) are also a strong indication of frost penetration in soils, being associated with frost heave and the growth of ice lenses (platy structure). ${ }^{58}$ Vertical or near-vertical grains (Table $2 \mathrm{~b}$ 
TAB LE 3 Summary of the slope processes and cryogenic environments

\begin{tabular}{|c|c|c|c|c|}
\hline Site name (sample code) & $\begin{array}{l}\text { Altitude } \\
\text { (m) }\end{array}$ & Aspect & Slope processes & Tentative cryogenic environment \\
\hline Penhas da Saúde & 1,520 & $\mathrm{~S}$ & Solifluction & Permafrost conditions \\
\hline Sítio das Pessoltas & 1,300 & NW & Solifluction & Permafrost conditions \\
\hline Vila Belo Horizonte & 1,260 & sW & Debris flow & Fluviatile-type flow conditions \\
\hline Barroca de Água & 1,000 & ESE & Debris flow & Paraglacial conditions \\
\hline Covão da Ponte & 990 & WNW & Solifluction & Seasonal frost conditions \\
\hline Sarzedo & 830 & WNW & Solifluction & Seasonal frost conditions \\
\hline Souto do Concelho & 700 & NNW & $\begin{array}{l}\text { Solifluction (primary deposition) followed by } \\
\text { post-depositional processes }\end{array}$ & $\begin{array}{l}\text { Seasonal frost conditions and } \\
\text { fluviatile-type flow conditions }\end{array}$ \\
\hline $\begin{array}{l}\text { São Gabriel (SG2U3 and } \\
\text { SG2U4) }\end{array}$ & 680 & NNE & $\begin{array}{l}\text { Solifluction (primary deposition) followed by } \\
\text { an illuvial phase }\end{array}$ & $\begin{array}{l}\text { Seasonal frost conditions and warmer and } \\
\text { humid conditions }\end{array}$ \\
\hline $\begin{array}{l}\text { São Gabriel (SG3U1 and } \\
\text { SG3U2) }\end{array}$ & 680 & NNE & $\begin{array}{l}\text { Solifluction (primary deposition) followed by } \\
\text { postdepositional processes }\end{array}$ & $\begin{array}{l}\text { Seasonal frost conditions and } \\
\text { fluviatile-type flow conditions }\end{array}$ \\
\hline Unhais da Serra & 650 & WSW & Solifluction & Seasonal frost conditions \\
\hline
\end{tabular}

and Figure 4e) can result from frost heave or frost jacking, occurring after the growth of ice lenses, especially during frost creep. ${ }^{58}$

Macroscopically, the ice lenses occur in units related to a sudden grain size change from coarse to fine (Figure 3a) and tend to occur in the lower part of the active layer, at the contact with the permafrost table. $^{20}$ Microscopically, the ice lenses have various shapes depending on the pattern of ice segregation in the soil. In samples PS2U3, PS3U3, and PS4U6 they are curved upwards, possibly related to a progressively slower rate of freezing with depth in sediments that are moist but not saturated ${ }^{20}$ and associated with fine sediments in solifluction sediments. ${ }^{59}$ Samples closer to the surface display perpendicular planar voids that are related to rapid cooling. ${ }^{21}$

Two of the samples closer to the surface (PS2U2, PS3U2) exhibit complex packing voids and granular microstructures (Table 2a). These two microfeatures are not exclusive of frostaffected soils and can be found in surface horizons of spodic materials (e.g., complex packing voids) or vertisols (e.g., granular). ${ }^{49}$ Nevertheless, granular microstructure is very common in frost-affected sediments having (sub)rounded aggregates and encircling finegrained coatings. They are usually observed in the upper part of the soil (this case), which is most susceptible to multidirectional frost and to frequent freeze-thaw cycles. ${ }^{20,48}$ Grain coatings and cappings (Figure $4 d, f$ ) are important pedofeatures that represent past freeze and thaw. ${ }^{20}$ The thickness of the coatings or cappings depends on how susceptible the fine material is to translocation. The samples exhibit layered (Figure 4d) and compound layered type of coatings/cappings, indicating strong eluviation of fine material that could result from melting of snow or ice lenses, or by fast freezing and/or under prolonged repeated freeze/thaw conditions. ${ }^{20}$ The abundant presence of fine materials is supported by well-developed chitonic-porphyric c/f-related distribution.

Rotation of (sub)rounded aggregates and consequent formation of downturned cappings along the surface are observed. They are probably the result of stresses induced at the grain/matrix interface during rotation, by solifluction, in the thaw phase when excess porewater pressures lead to a viscous downslope flow ${ }^{48}$ The circular arrangements of grains with a core grain (Figure 4a), rounded vesicles (Figure 4b), fine-grained deposits (Figure 4i) and matrix deformations (Figure $4 \mathrm{~h}$ ) are also strong evidence of rotation. ${ }^{8,48,50,59}$ They suggest disturbance and rotating movements in the matrix, occurring in response to velocity gradients within deforming sediments because of direct downward stress, probably in response to solifluction. Massive microstructures with an abundance of interconnected vughs (spongy microstructure) are observed, and although they are not exclusive of frost-affected soils, they are strongly related to mass-transported soil materials. $^{49}$

Although solifluction is not necessarily an indicator of the presence of permafrost, ${ }^{60}$ the set of micromorphological characteristics of these deposits strongly suggest its occurrence. According to Oliva et al. $^{61}$ paleopermafrost conditions in the lower latitude mountain ranges of the Iberian Peninsula occurred at $1,800 \mathrm{~m}$ in the Central Range (Gredos, 2,592 m; and Guadarrama, 2,430 m) and 2,500 m in the Sierra Nevada. In Serra da Estrela relict rock glaciers (1,220-1,340 m a.s.l.), ${ }^{32}$ which constitute the most frequent and reliable information on paleopermafrost occurrence in Mediterranean mountains, ${ }^{21,62}$ are scarce. Given the altitudinal range of the relict rock glaciers, the slope deposits from Penhas da Saúde and Covão da Malhada could have been produced under permafrost conditions. 


\section{2 | Sítio das Pessoltas (1,300 m), São Sebastião $(1,010 \mathrm{~m})$, and Covão da Ponte $(990 \mathrm{~m})$}

These three outcrops are identified as stratified slope deposits. They show an alternating openwork structure, matrix-supported layers, and fine and coarse beds (Figure 3a). These types of deposits have generally been attributed in the literature to periglacial processes and/or environments. ${ }^{63}$ Other studies attribute them to sheet wash processes, ${ }^{64}$ solifluction, ${ }^{7,65}$ dry grain flows, ${ }^{66}$ debris flows, ${ }^{67,68}$ or nivo-eolian transport. ${ }^{69}$ Sítio das Pessoltas presents a dark coloration in some units (Figure 3a) and may be ascribed to either pedogenic alteration (overprinting) or to postsedimentation ferruginization of coarse-textured layers, without soil development. The organic enrichment of some layers testifies to reworking and implies that the slope was partially de-vegetated at the time of sediment emplacement.

Microscopically the samples display variably shaped vughs (Table 2a), but they are not interconnected (spongy microstructure not observed). Indications of soil freezing are displayed through starshaped vughs associated with angular blocky microstructures ${ }^{20}$ in São Sebastião and with subangular blocky microstructures in Covão da Ponte (Table 2a). These two outcrops also indicate more abundant planar voids then Sítio das Pessoltas. In São Sebastião the planar voids display vertical and perpendicular ice growth directions and could be related to the development of angular blocky microstructures. As the units are at the surface of the outcrop, this could relate to rapid cooling. ${ }^{20}$ The planar voids from Covão da Ponte are thicker and have no apparent orientation. According to Van Vliet-Lanoë, ${ }^{51}$ the size of aggregates formed by ice lensing can increase progressively with depth, especially in sediments with larger grains, which is the case of Covão da Ponte (Metasediments, Table 1). This is due to the higher thermal conductivity, which results in a greater water supply for ice lens formation adjacent to coarser grains.

Sitio das Pessoltas displays complex packing voids and granular microstructures (Table 2a). Although, as previously mentioned, they are not exclusive to frost-affected soils, the observed microstructures indicate otherwise. With the granular microstructure, the rotation of sediment aggregates and consequent formation of downturned cappings are abundant, and probably result from differential frost heave and lateral displacement of the aggregates by solifluction. ${ }^{48,49}$ Granular aggregates can also be found in lower horizons, at the interface between two materials with different frost-susceptibilities or form in highly mobile solifluction lobes where there is temporary oversaturation of melt water. ${ }^{51,58}$ Circular arrangements of grains with a core grain (Figure 4a) and rounded vesicles (Figure 4b) are less abundant in these samples, as compared to the previous samples, and matrix deformations and fine-grained deposits are only observed in Sítio das Pessoltas (Table 2b). Nonetheless, these elements are thought to be associated with mechanical stresses and internal modifications in solifluction sediments. ${ }^{48}$

According to Oliva et al. ${ }^{61}$ sediments of periglacial origin, such as stratified deposits, could have been produced under permafrost conditions in the Iberian Peninsula, namely in the highest slopes and during the coldest stages. Permafrost conditions between 700 and 1,300 m were considered based on the presence of rock glaciers in northern mountain ranges (Cantabrian and Pyrenees mountains). Sitio das Pessoltas lies at the border of the altitudinal range of the relict rock glaciers in Serra da Estrela (1,220-1,340 $\mathrm{m}$ a.s.l.) and has a set of micromorphological characteristics that indicate that it could have been produced under permafrost conditions.

São Sebastião and Covão da Ponte are below the altitudinal range of the relict rock glaciers, and are on north-facing slopes. Topography in mountain areas determines different amounts of radiation in northern and southern slopes, affecting the spatial distribution and degree of activity of periglacial processes. Although these two outcrops also display a suite of micromorphological features, particularly abundant platy microstructures that can be linked to the presence of permafrost, ${ }^{21}$ such conditions have not been identified in lower latitude mountain ranges of the Iberian Peninsula. ${ }^{61}$

\section{3 | Vila Belo Horizonte (1,260 m), Barroca de Água (1,000 m), and São Gabriel (SG1U2, SG2U1 and SG2U2: $680 \mathrm{~m}$ )}

Samples from Vila Belo Horizonte, Barroca de Água, and São Gabriel (SG1U2 and SG2U1) were collected from units mainly consisting of different sized gravel and boulders with a weak to moderate preferred downslope orientation, in alternate silty-sandy or sandy-gravely material in a matrix-supported arrangement. These sedimentary properties reflect mass wasting processes of debris flow type. ${ }^{42,70,71}$ Buried fine materials (VBHU5), paleosols (SG2U4), or laminated overland-flow (SG2U2) deposits are usually found at the foot-slopes and are associated with this type of depositional process. $^{55}$

The samples show abundant complex packing voids that are common between coarse and fine grains (our case) and, also, in the upper part of spodic horizons. ${ }^{49}$ However, this type of horizon was not identified in the field. Microstructures in Vila Belo Horizonte are compact and pellicular, in Barroca de Água are bridged and pellicular, and the samples from São Gabriel show intergrain microaggregate, bridged and pellicular structures. These types of microstructures were identified by Texier and Meireles ${ }^{42}$ as fluviatile-type flows probably related to initial high-energy episodes. The c/f-related distribution is gefuric-chitonic (Vila Belo Horizonte and Barroca de Água) or enaulic-chitonic (SG1U2, SG2U1 and SG2U2) and related to clay and silt infillings during decreasing flow stages or postdepositional modifications ${ }^{55}$ (e.g., wetting and drying, freezing and thawing, bioturbation). The presence of banded microstructures in sample SG2U2 supports this observation. This microstructure shows larger grains at the bottom with progressively smaller grains toward the top and associated with a gradually waning sediment-laden current, depositing progressively finer material as the current velocity decreased. ${ }^{42}$ 
Weakly developed circular arrangements of grains without a core grain were identified (Table 2b), except in sample SG2U2. Menzies and Zaniewski ${ }^{72}$ compared the micromorphological characteristics of a fresh debris flow deposit with Quaternary glacial deposits. Although microscopic similarities were identified, the main difference was the presence of a circular arrangement of grains without a core grain (grain turbate) in the Quaternary glacial deposits. The same specific microfeature was also found by Phillips $^{73}$ near the base of a Pleistocene debris flow and by Harris ${ }^{54}$ in paraglacial deposits. They suggest that this type of microfeature develops in response to transitory rotational deformation associated with turbulent flow in the matrix of the sediments.

Coarse grain lineations (Figure $4 \mathrm{j}$ ) are abundant in all samples (Table 2b). They form in response to parallel stresses during shear, because of the combination of stretching and shortening that eventually lead the grains to become aligned, which is regarded as a stress relief phenomenon. ${ }^{50}$ Fine grain lineations (Figure $4 \mathrm{k}$ ) were identified only in samples SG2U1 and SG2U2 (Table 2b) and form in response to parallel stresses during planar shear. ${ }^{72,73}$ These two types of microfeatures were identified in fresh debris flow deposits by Menzies and Zaniewski. ${ }^{72}$

Fine grain coatings (Figure 4e) and grain dumps (Figure 4g) are abundant (Table 2b) and can be attributed to translocation of particles by percolation water when the deposition loses competence ${ }^{50,55}$ or by postdepositional processes. ${ }^{42}$ Van Vliet-Lanoë recognized fine grain coatings in debris flow deposits in periglacial environments and identified them as a result of liquefaction.

Oblique grains (Figure 4e) in a subhorizontal position are abundant (Table $2 \mathrm{~b}$ ) and can result from porewater moving through the sediments and the long axes of clasts and matrix particles are reoriented in the direction of the porewater pathway. Todisco and Bhiry ${ }^{48}$ indicated that abundant subhorizontally aligned long pebbles can suggest short-distance low-energy transport, probably related to an accumulation stage of the debris flow sediments on the foot slope.

The azonal character of debris flows is well known. ${ }^{4}$ The environmental parameters that trigger this process (e.g., high-intensity rainfall, poorly cohesive detrital mantle and zones where runoff water can concentrate) probably coexisted throughout the Quaternary in the study area. Although some microfeatures observed in our samples are found in debris flows in periglacial and nonperiglacial environments, only one was exclusively found in frost-related settings (e.g., circular arrangement of grains without a core grain). In our samples they are not abundant (Table $2 \mathrm{~b}$ ), and hence it is not clear if this process was generated under cold environmental conditions. Barroca de Água is the only outcrop located inside the glaciated area (Figure 1), so deposition in a paraglacial environment could have been possible.

\subsection{Poço do inferno (1,008 m), Sarzedo (830 m), and Unhais da Serra (650 m)}

The slope deposits from these sites are composed of units with different sized boulders (Poço do Inferno and Unhais da Serra) and a diamicton (Sarzedo) in a silty-sandy or sandy-gravely matrix and a well-developed preferred clast orientation parallel to the slope (Figure 2a, b). Deformation features such as folds are observed in Unhais da Serra. The macroscopic characteristics could indicate a solifluction origin, but strongly slope-oriented clast fabrics have been observed with other deposition processes ${ }^{42}$ (e.g., debris flows). Also, in contrast to the outcrops of Penhas da Saúde and Covão da Malhada, we did not observe massive units with lenticular segregated ice-form lenses.

Microscopically, frost-related evidence such as platy microstructures is abundant only in Sarzedo (Table 2a). Poço do Inferno has abundant granular microstructures, which are not exclusive evidence of periglacial conditions, as described previously. However, all the samples have specific microfeatures related to cryogenic processes, ${ }^{48}$ namely a circular arrangement of grains (Figure 4a), rounded vesicles (Figure 4b), vertical grains (Figure 4e), and matrix deformations (Figure 4h). Poço do Inferno and Sarzedo provide the few samples that have a high abundance of crushed grains (Table $2 b$ ). They result from mechanical cracking, indicating increase moisture retention in a fissure with subsequent ice growth, resulting in frost shattering. ${ }^{49,74,75}$

The three outcrops have a set of micromorphological features which are related to periglacial environments, but permafrost conditions are not certain, as the deposits are located below the altitudinal range of the relict rock glaciers in Serra da Estrela (1,220-1,340 $\mathrm{m}$ a.s.I.). Sarzedo has abundant platy microstructures, which can be linked to the presence of permafrost ${ }^{21}$ and could be an indication of these conditions at much lower altitudes then previously recorded in the mountains of the Iberian Peninsula Central Range. ${ }^{61}$ Poço do Inferno and Unhais da Serra, do not have abundant platy microstructures, but nonetheless have a group of microfeatures that could indicate permafrost conditions or seasonal front conditions. Unhais da Serra is the only of the three outcrops on a south-facing slope (Table 1) and periglacial evidence at such a low altitude has only been found in the Cantabrian Mountains (northern Iberian Peninsula). ${ }^{21}$

\section{5 | Souto do concelho (700 m) and São Gabriel (SG3U1 and SG3U2: $680 \mathrm{~m}$ )}

The samples from Souto do Concelho were collected from clastsupported diamicton with a well-developed preferred clast orientation parallel to the slope (Figure 3b). São Gabriel (SG3U1 and SG3U2) samples are from a matrix-supported diamicton with a moderately to welldeveloped preferred orientation parallel to the slope. Massive units with lenticular segregated ice-form lenses were not observed and deformation features such as folds were only found in SG3U2.

Microscopically, these samples have complex packing voids associated with a granular microstructure (Table 2b). As noted above, these microstructures are not exclusive to any environment. The absence of planar voids could indicate a nonfrost influence on these sediments. Bridged and pellicular microstructures (Table 2a) 
are also observed, and this type of microstructure is related to fluviatile-type flows. ${ }^{42}$ The c/f-related distribution is gefuricchitonic (SCU2) or enaulic-chitonic (SCU3, SG3U1 and SG3U2) (Table $2 b$ ), related to fine material infillings during reduced flow stages or postdepositional modifications. ${ }^{55}$

Large differences in microfeatures were found among the different samples. In Souto do Concelho, a circular arrangement of grains (Figure 4a), rounded vesicles (Figure 4b), and vertical grains (Figure 4e) are moderately abundant (Table 2b). These microfeatures are probably related to solifluction processes. ${ }^{48}$ The buried soil in Souto do Concelho (Figure 2b) was radiocarbon-dated $\left({ }^{14} \mathrm{C}\right)$ to $13,920 \pm 70 \mathrm{BP}$. Texier and Meireles ${ }^{42}$ identified organic layers in the mountains of northern Portugal at similar altitudes with similar results. The age from the soil indicates a favurable phase for pedogenic processes and is concurrent with results from Van der Knaap and Van Leeuwen ${ }^{44}$ obtained in Serra da Estrela. Climate conditions between 14,060 and 12,850 cal. a BP (Allerød) indicated an increase in temperature and precipitation and that closed treeless vegetation extended to above 1,845 $\mathrm{m}$ a.s.l. During this phase, between 12,850 and 11,875 a BP temperature decreased, and the climate became colder and drier (Younger Dryas) with a marked reduction in vegetation. This cold climate regime promoted a down-valley expansion of periglacial activity in the Iberian Peninsula mountains, reaching lower elevations. ${ }^{21}$ This stage could have influenced the development of frost-induced microfeatures during deposition in Souto do Concelho, reinforced by its north-facing position.

Microfeatures from São Gabriel (SG3U1 and SG3U2) include abundant oblique grains (Figure 4e), grain dumps (Figure 4g) and finegrained lineations (Figure 4k) (Table $2 \mathrm{~b}$ ) and these microfeatures have been related to flow-like deposits. ${ }^{55}$ According to these results, the depositional processes at the two sites are not definitive. They have macro- and microstructures indicating fluviatile-type flows and solifluction. Postdepositional processes could have altered the original microstructures and thus complicate the analysis and dynamic interpretation. Bertran et al. ${ }^{55}$ have shown that when such modifications are important, macroscopic evidence provides the most useful information for interpretation of slope deposits, because sedimentary structures are often preserved and can be used most effectively. Following this recommendation, the macrostructures indicate solifluction deposition, but the original micromorphological structures were altered by postdeposition processes related to fluvial-type events.

\section{6 | São Gabriel (SG2U3 and SG2U4)}

The sample SG2U4 was collected from a paleosol (Figure $3 \mathrm{~b}$ ) and was radiocarbon-dated $\left({ }^{14} \mathrm{C}\right)$ to $25,260 \pm 250$ a BP. ${ }^{16}$ This indicates that pedogenic processes occurred during this stage. Nieuwendam ${ }^{76}$ reconstructed a slight warming period around this age in the northern Iberian Peninsula mountains as did Texier and Meireiles ${ }^{42}$ for northern Portugal. Sample SG2U3 was collected at the border between the paleosol and the diamicton (Figure $3 \mathrm{~b}$ ). It is a matrix-supported diamicton with well-developed preferred clast orientation parallel to the slope. The paleosol shows a massive structure. Our microscopic analyses of the two samples showed that SG2U3 had strong soil characteristics, such dark brown color aggregates due to organic matter. ${ }^{77}$ This was surprising because the sample was taken from a unit where macroscopically no soil signs were found. This could indicate that the paleosol was affected by processes of in-situ reworking, erosion, transport, or post-deposition. ${ }^{77}$

The samples have complex packing, vughs, and planar voids. Although, the planar voids are not abundant, they are a key indicator that frost action has affected these samples at some point. When repetitive freeze-thaw cycles affect a paleosol, platy microstructures can be affected by internal micro-erosion. ${ }^{20}$ Subangular blocky and granular microstructures are observed. The combination of these type of voids and microstructures were also observed in the samples of Penhas da Saúde and Covão da Malhada and connected to cryogenic processes. Correspondingly, granular aggregates when observed in paleosol are often related to past permafrost or sometimes confused with crumb microstructures produced by biological activity. ${ }^{20}$ Nevertheless, no traces of biological microfeatures were identified. We believe this paleosol was formed by transported soil materials (pedosediments), given the presence of packing of rounded aggregates and absence of in-situ biogenic features. ${ }^{77}$ This is supported by the presence of clay coating fragments dispersed in the groundmass that indicated the formation of the soil was interrupted by a masstransportation process, followed, in turn, by an illuvial phase during which silt grains were also translocated. ${ }^{77}$

Intergrain microaggregate microstructures, and coarse grain and fine gain lineations are abundant and, as discussed previously, they are associated with surface run-off events. ${ }^{42,72}$ This is reinforced by the $\mathrm{c} / \mathrm{f}$-related distribution type (enaulic-chitonic) and grain dumps (Figure $4 \mathrm{~g}$ ), which are related to the translocation of particles by percolation water when surface run-off deposition loses competence ${ }^{50,55}$ or by postdepositional processes. ${ }^{42}$ These microscale characteristics are found in either, reworked soils or masstransported soils. ${ }^{77}$ This suggests that the soils were periodically destabilized by drastic climatic events.

Microstructures such as circular arrangements of grains with a core grain which indicate rotation in response to solifluction and vertical or near-vertical grains that result from frost heave are found in both samples. ${ }^{48,51,55,58,59}$ Therefore, this paleosol was probably affected by a combination of: (a) mass-transport, which at some point could be related to solifluction process during a glacial phase; and (b) illuvial phases, which could have occurred be during a warmer period.

\section{6 | CONCLUSIONS}

This study shows that micromorphology as a technique for the analysis of sediments from relict slope deposits allows for significant advances in identifying slope processes and past environmental conditions, when compared to classical macroscopic analyses. However, it 
is necessary to use several criteria such as macro- and microscopic structures and granulometry for reliable diagnosis of the studied sediments. This study has described the facies and microstructures of relict slope deposits of Serra da Estrela to understand their morphogenetic settings and compared the results with geomorphological evidence across varying altitudes, resulting in a robust interpretation of paleoenvironmental conditions.

The intensity of the frost-related microfeatures, such as platy microstructures, increases with increasing altitude, having a higher frequency in slope sediments above $1,300 \mathrm{~m}$ a.s.l. This agrees with the elevation range of relict rock glaciers that are an important permafrost indicator in mountain environments. Although frost-related microfeatures are found on north-facing slopes as low as $650 \mathrm{~m}$ a.s.l., no geomorphological evidence was found indicating that permafrost existed at elevations lower than 1,300 a.s.l. It is therefore more likely that the results derived from micro- and macro-analyses came from intensive seasonal frost rather than from the the presence of permafrost at those sites.

\section{ACKNOWLEDGEMENTS}

A.N. benefited from a PhD grant from the Portuguese Foundation for Science and Technology (grant reference SFRH/BD/68511/2010). Field work and visits of A.N. to the University of Warsaw were partially funded by the Centro de Estudos Geográficos, IGOT, University of Lisbon (national funds FCT - UID/GEO/00295/2013) and Associação Geopark Estrela (AGE). Laboratory analysis at the Federal University of Viçosa (Brasil) were conducted in the framework of the project FCT-CAPES Luso-Brazilean program for research on permafrost and terrestrial ecosystems of the Maritime Antarctic (2011-12). Mr José Maria Saraiva is thanked for his support during field work and facilities provided at the Parque de Campismo do Camalhão in Verdelhos. Many thanks to the reviewers for their comments on an early draft of this paper.

\section{ORCID}

Alexandre Nieuwendam (D) https://orcid.org/0000-0003-3827-1132 Gonçalo Vieira (D) https://orcid.org/0000-0001-7611-3464 Carlos Schaefer (D) https://orcid.org/0000-0001-7060-1598 Barbara Woronko (D) https://orcid.org/0000-0002-2763-5650 Margareta Johansson (D) https://orcid.org/0000-0001-9650-7153

\section{REFERENCES}

1. Clark M, Small J. Slopes and Weathering. Cambridge Topics in Geography, second series. Cambridge, UK: Cambridge University Press; 1982.

2. Dewolf Y, Bourrié G. Les Formations Superficielles. Genèse-TypologieClassification. Paysages et Environnements. Ressources et Risques. Paris, France: Ellipses; 2008.

3. van der Meer J, Menzies J. The micromorphology of unconsolidated sediments. Sediment Geol. 2011;238(3-4):213-232. https://doi.org/ 10.1016/j.sedgeo.2011.04.013

4. Van Steijn HV, Boelhouwers J, Harris S, Hétu B. Recent research on the nature, origin and climatic relations of blocky and stratified slope deposits. Progr Phys Geogr. 2002;26(4):551-575. https://doi.org/10. 1191/0309133302pp352ra
5. Bertran P, Coutard JP, Francou B, Ozouf JC, Texier JP. Nouvelles données Sur l'origine du litage des grèzes. Implications paléoclimatiques. Géogr Phys Quatern. 1992;46(1):97-112. https://doi. org/10.7202/032891ar

6. Hétu $B$, van Steijn $H$, Bertran P. Le rôle des coulées de pierres sèches dans la genèse d'un certain type d'éboulis stratifiés. Permafrost Periglac Process. 1995;6(2):173-194. https://doi.org/10.1002/ppp.3430060212

7. Van Steijn H, Bertran P, Francou B, Hétu B, Texier JP. Review of models for genetical interpretation of stratified slope deposits. Permafrost Periglac Process. 1995;6(2):125-146. https://doi.org/10.1002/ ppp.3430060210

8. Bertran P, Hétu B, Texier JP, Van Steijn H. Fabric of subaerial slope deposits. Sedimentology. 1997;44(1):1-16. https://doi.org/10.1111/j. 1365-3091.1997.tb00421.x

9. Van Vliet-Lanoë B. Cryoreptation, gélifluxion et coulées boueuses: une dynamique de solifluxion continue en relation avec le drainage et la stabilité de l'agrégation cryogénique. In: Pécsi M, French HM, eds. Loess and Periglacial Phenomena. Budapest, Hungary: Akadémiaì Kiadó; 1987:191-201.

10. Bullock P, Fedoroff N, Jongerius A, Stopps G, Tursina T, Babel U. Handbook for Soil Thin Section Description. Wolverhampton, UK: Waine Research Publications; 1985.

11. Fitzpatrick EA. Soil Microscopy and Micromorphology. New York, NY: Wiley; 1993.

12. Schaefer C, Simas F, Gilkes R, Mathison C, Costa L, Alburquerque M. Micromorphology and microchemistry of selected Cryosols from maritime Antarctica. Geoderma. 2008;144(1-2):104-115. https://doi.org/ 10.1016/j.geoderma.2007.10.018

13. Van Vliet-Lanoë B, Coutard JP, Pissart A. Structures caused by repeated freezing and thawing in various loamy sediments: a comparison of active, fossil and experimental data. Earth Surf Process Landf. 1984;9(6):553-565. https://doi.org/10.1002/esp.3290090609

14. Harris C. Geomorphological applications of soil micromorphology with particular reference to periglacial sediments and processes. In: Richards KS, Arnett RR, Ellis S, eds. Geomorphology and Soils. London, UK: George Allen and Unwin; 1985.

15. Van Vliet-Lanoë B. The significance of cryoturbation phenomena in environmental reconstruction. J Quaternary Sci. 1988;3(1):85-96. https://doi.org/10.1002/jqs.3390030110

16. Van Vliet-Lanoë B. Differential frost heave, load casting and convection: converging mechanisms; a discussion of the origin of cryoturbations. Permafrost Periglacl Process. 1991;2(2):123-139. https://doi.org/10.1002/ppp.3430020207

17. Bertran $P$, Fontugne $M$, Jaubert J. Permafrost aggradation followed by brutal degradation during the upper Pleniglacial in Mongolia: the probable response to the $\mathrm{H} 2$ Heinrich event at 21 kyr BP. Permafrost Periglac Process. 2003;14(1):1-9. https://doi.org/10.1002/ppp.435

18. Elliott G, Worsley P. The sedimentology, stratigraphy and ${ }^{14} \mathrm{C}$ dating of a turfbanked solifluction lobe: evidence for Holocene slope instability at Okstindan, northern Norway. J Quaternary Sci. 1999;14(2): 175-188. https://doi.org/10.1002/(SICI)1099-1417(199903)14: $2<175:: A I D-J Q S 432>3.0 . C O ; 2-6$

19. Mol J, Vandenberghe J, Kasse K, Stel H. Periglacial microjointing and faulting in Weichselian fluvio-aeolian deposits. J Quaternary Sci. 1993;8(1):15-30. https://doi.org/10.1002/jqs.3390080103

20. Van Vliet-Lanoë B. Frost Action. In: Stoops G, Marcelino V, Mees F, eds. Interpretation of Micromorphological Features of Soils and Regoliths. Elsevier: Amsterdam; 2010:81-108 DOI: 10.1016/ B978-0-444-53156-8.00006-4.

21. Oliva M, Serrano E, Gómez-Ortiz A, et al. Spatial and temporal variability of periglaciation of the Iberian Peninsula. Quaternary Sci Rev. 2016;137:176-199. https://doi.org/10.1016/j.quascirev.2016. 02.017

22. Vieira GT, Cordeiro AMR. Geomorfologia periglaciária em Portugal: Estado do conhecimento. In: Gómez Órtiz A, Salvador Franch F, 
Schulte L, García Navarro A, eds. Procesos biofisicos actuales en medios frios. Estudios recientes. Barcelona, Spain: Publ. Universitat de Barcelona; 1998:347-371.

23. Daveau S. Quelques exemples d'évolution quaternaire des versants au Portugal. Finisterra. 1973;8(15):5-47. https://doi.org/10.18055/ Finis2391

24. Daveau S. Le périglaciaire d'altitude au Portugal. Colloque Sur le périglaciaire d'altitude du domaine méditerranéen et ses abords. Association Géographoque d' Álsance. Strasbourg. 1978; 63-78.

25. Ferreira AB. Manifestações geomorfológicas glaciárias e periglaciárias em Portugal. In: Carvalho GS, Ferreira AB, Senna-Martínez JC, eds. O Quaternário em Portugal: Balanço e perspectivas. Lisbon, Portugal: A.P. E.Q. Colibri; 1993:75-84.

26. Guitián MR, Pérez-Alberti A, Díaz MV. Reconstrucción paleoambiental a partir de las formas y depósitos superficiales en el limite Galaico-AsturLeonés. 3a Reunião do Quaternário Ibérico. Coimbra, Portugal: Actas; 1995:191-198.

27. Vieira GT. Periglacial research in the Serra da Estrela: an overview. In: Vieira GT, ed. Glacial and Periglacial Geomorphology of the Serra da Estrela. Guidebook for the field-trip, IGU Commission on Climate Change and Periglacial Environments, 26-28 August 1998. Lisbon, Portugal: CEG and Department of Geography, University of Lisbon; 1998: 49-65.

28. Pérez-Alberti A, Blanco Chao R, Costa Casais M. Depósitos sedimentarios antiguos en la costa atlántica gallega: tipología, localización y área fuente. Un análisis comparativo. In: Gómez Ortiz A, Salvador Franch F (eds.) Investigaciones Recientes de la Geomorfología Española. Universitat de Barcelona, Barcelona. 1998;341-346.

29. Rodrigues ML. Evolução geomorfológica quaternária e dinâmica actual: aplicações ao ordenamento do território: exemplos no maciço cálcario estremenho. Dissertação de doutoramento. Lisbon, Portugal: Universidade de Lisboa; 1998.

30. Pérez-Alberti A, Valcárcel Díaz M. Descripción e interpretación de depósitos de ladera estratificados en la Galicia Oriental. In: Tena MVL, Monné JLP, Fabre MS, eds. Procesos y formas periglaciares en la montaña mediterránea: ponencias. Presentadas en la IV Reunión I.P.A.-España, Albarracín. España: Instituto de Estudios Turolenses; 2000:25-44.

31. García-Ruiz JM, Valero-Garcés B, González-Sampériz P, et al. Stratified scree in the central Spanish Pyrenees: palaeoenvironmental implications. Permafrost Periglac Process. 2000;12(3):233-242. https://doi.org/10.1002/ppp.388

32. Vieira G. Geomorfologia dos Planaltos e altos vales da Serra da Estrela: Ambientes frios do Plistocénico superior e dinâmica actual. Dissertação de doutoramento. Lisbon, Portugal: Universidade de Lisboa; 2004.

33. Vieira G, Mora C, Ramos M. Ground temperature regimes and geomorphological implications in a Mediterranean mountain (Serra da Estrela, Portugal). Geomorphology. 2003;52(1):57-72. https://doi.org/ 10.1016/S0169-555X(02)00248-9

34. Oliva M, Gómez-Ortiz A, Salvador-Franch F, Salvá-Catarineu M. Present day solifluction processes in the semiarid range of Sierra Nevada (Spain). Arct Antarc Alp Res. 2014;46(2):73-78. https://doi.org/10. 1657/1938-4246-46.2.365

35. Serrano E, San José JJ, Agudo C. Rock glacier dynamics in a marginal periglacial high mountain environment: flow, movement (1991-2000) and structure of the Argualas rock glacier, the Pyrenees. Geomorphology. 2006;74(1):285-296. https://doi.org/10.1016/j.geomorph.2005.08.014

36. Ferreira $A B$, Rodrigues $M L$, Vieira GT. Manifestações herdadas e actuais de climas frios em Portugal. In: Peña Monné JL, Sánchez Fabre M, Lozano Tena MV, eds. Procesos y formas periglaciares en la montaña mediterránea. Teruel, Spain: Instituto de Estudios Turolenses; 2000:161-190.

37. Vieira G. Combined numerical and geomorphological reconstruction of the Serra da Estrela plateau icefield, Portugal. Geomorphology. 2008;97:190-207. https://doi.org/10.1016/j.geomorph.2007.02.042
38. Rebelo F. Os processos erosivos actuais no Norte e Centro de Portugal. Coimbra: (Projecto de investigação); 1975.

39. Cunha L. As Serras Calcárias de Condeixa-Sicó-Alvaiázere - Estudo de Geomorfologia. Instituto Nacional de Investigação Científica. Geografia Física 1. Coimbra. 1990.

40. Cordeiro AMR. Dinâmica de vertentes em montanhas ocidentais do Portugal central. Dissertação de doutoramento. Coimbra, Portugal: Universidade de Coimbra; 2004.

41. Migoń P, Vieira G. Granite geomorphology and its geological controls, Serra da Estrela, Portugal. Geomorphology. 2014;226:1-14. https:// doi.org/10.1016/j.geomorph.2014.07.027

42. Texier JP, Meireles J. Relict mountain slope deposits of northern Portugal: facies, sedimentogenesis and environmental implications. J Quaternary Sci. 2003;18(2):133-150. https://doi.org/10.1002/ jqs.752

43. Van der Knaap WO, Van Leeuwen, JFN. Holocene vegetation, human impact, and climatic change. In: festschrift Gerhard Lang. AF Lotter \& Ammann ed. The Serra da Estrela, Portugal. Dissertationes Botanica. 1994; 234: 234-535.

44. Van der Knaap WO, Van Leeuwen JFN. Late glacial and early Holocene vegetation succession, altitudinal vegetation zonation, and climate change in the Serra da Estrela, Portugal. Rev Palaeobot Palynol. 1997;97(3-4):239-285. https://doi.org/10.1016/S0034-6667(97) 00008-0

45. Hubbard B, Glasser L. Field Techniques in Glaciology and Glacial Geomorphology. Chichester: John Wiley \& Sons, Ltd; 2005.

46. Brewer R. Fabric and mineral analysis of soils. New York, NY: John Wiley \& Sons; 1964.

47. Stoops G. Guidelines for analysis and description of soil and regolith thin sections. Madison, WI: Soil Science Society of America; 2003 DOI: 10. 1017/S002185960322339X.

48. Todisco D, Bhiry N. Micromorphology of periglacial sediments from the Tayara site, Qikirtaq Island, Nunavik (Canada). Catena. 2008;76(1): 1-21. https://doi.org/10.1016/j.catena.2008.08.002

49. Stoops G, Marcelino V, Mees F. Interpretation of Micromorphological Features of Soils and Regoliths. Amsterdam, the Netherlands: Elsevier; 2010.

50. Linch L, Dowdeswell J. Micromorphology of diamicton affected by iceberg-keel scouring, Scoresby Sund, East Greenland. Quaternary Sci Rev. 2016;152:169-196. https://doi.org/10.1016/j.quascirev.2016. 09.013

51. Van Vliet-Lanoë B, Fox C, Gubin S. Micromorphology of Cryosols. In: Kimble JM, ed. Cryosols: Permafrost-affected Soils. Berlin, Germany: Springer-Verlag; 2004 DOI: 10.1007/978-3-662-06429-0_18.

52. Bertran P. Deformation-induced microstructures in soils affected by mass movements. Earth Surf Process Landf. 1993;18(7):645-660. https://doi.org/10.1002/esp.3290180707

53. Elliott G. Microfabric evidence for podzolic soil inversion by solifluction processes. Earth Surf Process Landf. 1996;21(5):467-476. https:// doi.org/10.1002/(SICl)1096-9837(199605)21:5<467::AIDESP665>3.0.CO;2-V

54. Harris $\mathrm{C}$. The micromorphology of paraglacial and periglacial slope deposits: a case study from Morfa Bychan, West Wales, UK. J Quaternary Sci. 1998;13(1):73-84. https://doi.org/10.1002/(SICI) 1099-1417(199801/02)13:1<73::AID-JQS315>3.0.CO;2-P

55. Bertran P, Texier JP. Facies and microfacies of slope deposits. Catena. 1999;35:99-121. https://doi.org/10.1016/S0341-8162(98) 00096-4

56. French $\mathrm{H}$. The Periglacial Environment. Third ed. Chichester, UK: John Wiley \& Sons, Ltd. DOI: 10.1002/9781118684931.

57. Bockheim JG, Tarnocai C. Recognition of cryoturbation for classifying permafrost-affected soils. Geoderma. 1998;81(3-4):281-293. https:// doi.org/10.1016/s0016-7061(97)00115-8

58. Van Vliet-Lanoë B. Frost effects in soils. In: Boardman J, ed. Soils and Quaternary Landscape Evolution. Chichester, UK: Wiley; 1985. 
59. Bertran P, Francou B, Texier JP. Stratified slope deposits: the stonebanked sheets and lobes model. In: Slaymaker O, ed. Steepland Geomorphology. Chichester, UK: Wiley; 1995:147-169.

60. Matsuoka N. Solifluction rates, processes and landforms: a global review. Earth Sci Rev. 2001;55(1-2):107-134. https://doi.org/10. 1016/S0012-8252(01)00057-5

61. Oliva M, Zebre M, Guglielmin M, et al. Permafrost conditions in the Mediterranean region since the last glaciation. Earth Sci Rev. 2018; 185:397-436. https://doi.org/10.1016/j.earscirev.2018.06.018

62. Serrano E. Glaciares rocosos. Controversias y certidumbres. In: Gómez-Ortiz A, Salvador F, Oliva M, Salvá M, eds. Avances, métodos y técnicas en el estudio del periglaciarismo. Barcelona, Spain: Universitat de Barcelona; 2014:115-134.

63. Dewolf Y. Stratified slope deposits. In: Clark MJ, ed. Advances in periglacial geomorphology. New York, NY: Wiley; 1988:91-110.

64. Harris SA, Prick A. Conditions of formation of stratified screes, Slims River valley, Yukon territory: a possible analogue with some deposits from Belgium. Earth Surf Process Landf. 2000;25(5):463-481.

65. Bertran $P$, Francou $B$, Pech $P$. Stratogenèse associéeà la dynamique des coulées à front pierreux en milieu alpin, La Mortice, Alpes Méridionales, France. Géogr Phys Quatern. 1993;47(1):93-100. https:// doi.org/10.7202/032933ar

66. Hétu B, Van Steijn H, Vandelac P. Les coulées de pierres glacées: un nouveau type de pierraille Sur les talus d'éboulis. Géogr Phys Quatern. 1994;48(1):3-22. https://doi.org/10.7202/032969ar

67. Van Steijn H, De Ruig J, Hoozemans F. Morphological and mechanical aspects of debris flows in part of the French Alps. Z Geomorphol. 1988;32(2):143-161.

68. Bertran P, Texier JP. Structures sédimentaires d'un cõne de flots de débris (Vars, Alpes françaises méridionales). Permafrost Periglac Process. 1994;5(3):155-170. https://doi.org/10.1002/ppp.3430050305

69. Hétu B. Eboulis stratifiés actifs près de Manche d'Épée, Gaspésie (Québec, Canada). Z Geomorphol. 1991;35(4):439-461.

70. Van Steijn H. Debris flows involved in the development of Pleistocene stratified slope deposits. Z Geomorphol Neue Folge. 1988;71:45-58.

71. Van Steijn H. Frequency of hillslope debris flows in a part of the French Alps. Turkish Bull Geomorphol (Ankara). 1991;19:83-90.

72. Menzies J, Zaniewski K. Microstructures within a modern debris flow deposit derived from quaternary glacial diamicton - a comparative micromorphological study. Sediment Geol. 2003;157(1-2):31-48. https://doi.org/10.1016/S0037-0738(02)00193-8

73. Phillips E. Micromorphology of a debris flow deposit: evidence of basal shearing, hydrofracturing, liquefaction and rotational deformation during emplacement. Quaternary Sci Rev. 2006;25(7):720-738. https://doi.org/10.1016/j.quascirev.2005.07.004

74. Woronko B. Frost weathering versus glacial grinding in the micromorphology of quartz sand grains: processes and geological implications. Sediment Geol. 2016;335:103-119. https://doi.org/10.1016/j.sedgeo. 2016.01.021

75. Woronko B, Pisarska-Jamroży M. Micro-scale frost weathering of sand-sized quartz grains. Permafrost Periglac Process. 2016;27(1):109122. https://doi.org/10.1002/ppp.1855

76. Nieuwendam A, Ruiz-Fernández J, Oliva $M$, Lopes $V$, Cruces A. Freitas M.C. 2015. Postglacial landscape changes and cryogenic processes in the Picos de Europa (northern Spain) reconstructed from geomorphological mapping and microstructures on quartz grains. Permafrost Periglac Process. 2015;27(1):96-108. https://doi.org/10. 1002/ppp.1853

77. Fedoroff N, Courty MA, Guo Z. Palaeosoils and relict soils. In: Stoops G, Marcelino V, Mees F, eds. Interpretation of Micromorphological Features of Soils and Regoliths. Amsterdam, the Netherlands: Elsevier; 2010:81-108 DOI: 10.1016/B978-0-444-53156-8.00006-4.

\section{SUPPORTING INFORMATION}

Additional supporting information may be found online in the Supporting Information section at the end of this article.

How to cite this article: Nieuwendam A, Vieira G, Schaefer C, Woronko B, Johansson M. Reconstructing cold climate paleoenvironments from micromorphological analysis of relict slope deposits (Serra da Estrela, Central Portugal). Permafrost and Periglac Process. 2020;31:567-586. https://doi.org/ 10.1002/ppp.2054 